\title{
Risk Management with Derivatives by Dealers and Market Quality in Government Bond Markets
}

\author{
by \\ Narayan Y. Naik and Pradeep K. Yadav ${ }^{1}$ \\ This draft: $21^{\text {st }}$ September 2001 \\ JEL Classification: G10, G20, G24
}

\begin{abstract}
${ }^{1}$ Narayan Y. Naik is from the London Business School, Sussex Place, Regent's Park, London NW1 4SA, U.K. (http://www.london.edu/faculty research/, tel. +44 207 2625050, e-mail nnaik@london.edu). Pradeep K. Yadav is from the University of Strathclyde, 100 Cathedral Street, Glasgow, G4 OLN, U.K, and is currently visiting the Stern School at New York University (http://www.stern.nyu.edu/ pyadav, tel. 212-9980305, e-mail pyadav@stern.nyu.edu). We would like to thank the Bank of England for providing us with the inventory positions of government bond dealers. We are very grateful to Richard Brealey, Allison Holland, Francis Longstaff and John Merrick for detailed discussions. We are also grateful to an anonymous referee, Yakov Amihud, Vikas Agarwal, Michael Brennan, Roger Brown, Bhagwan Chowdhury, Pedro Santa-Clara, Steve Figlewski, Robert Geske, Rick Green, David Hillier, Purnendu Nath, Darius Palia, Venketesh Panchpagesan, Richard Roll, Stephen Schaefer, Eduardo Schwartz, Richard Stapleton, seminar participants at the London Business School, University of Strathclyde, the Anderson School at UCLA, University of Cologne, the Western Finance Association Meetings, the European Finance Association Meetings and the Annual Meeting of the International Association of Financial Engineers, for many helpful comments and suggestions on an earlier version of this paper. Part of this work was undertaken while Pradeep Yadav was visiting the Anderson School at UCLA. We thank Etleva Skenderi for excellent research assistance. Both authors thank the European Commission's TMR program grant (network reference ERBFMRXCT 960054) for financial support and the Scottish Institute for Research in Investment and Finance (SIRIF) for infrastructural support. Both authors are also grateful to the Fisher Black Memorial Foundation and the International Association of Financial Engineers for awarding an earlier version of this paper the Year 2000 Robert J. Schwartz Memorial Prize.
\end{abstract}




\title{
Risk Management with Derivatives by Dealers and Market Quality in Government Bond Markets
}

\begin{abstract}
This paper examines how bond dealers use futures markets to manage the hedgeable market risk component of their core business risk exposure, and whether market quality is adversely affected by their selective risk taking activity. It also investigates the efficiency of market risk sharing within a decentralized semi-transparent market structure. We find that dealers engage in duration targeting, behaving as if they have a comparative advantage in bearing interest rate risk. They make significant directional bets often by holding futures that are in the same direction as the spot. They actively use futures to hedge changes in the spot exposure. They hedge changes in their spot exposure more when the potential costs of regulatory distress are high, when the cost of such hedging is low, and during periods of greater uncertainty. We find that duration targeting by dealers has adverse price effects due to capital constraints as predicted by Froot and Stein (1998). Finally, we find that trades in the spot market are not executed by dealers with extreme exposures. In this context, we recommend market reforms such as introduction of central quote posting or limit order book that will enable more efficient matching of liquidity demanders and suppliers, reduce trading costs, and improve the quality of risk sharing.
\end{abstract}




\section{Risk Management with Derivatives by Dealers and Market Quality in Government Bond Markets}

The risk management practices of corporations have received wide attention in recent years largely due to some well-publicised cases of losses incurred by firms as a result of trading in derivatives $^{1}$. The theoretical literature provides several motivations for why corporations should use derivatives to manage their risk ${ }^{2}$. From an empirical perspective, our understanding of corporate risk management practices has improved significantly in recent years, thanks to Wharton/CIBC surveys, to changes in the public disclosure requirements that has enabled extensive empirical research, and to case studies that describe the risk management practices of specific firms and industries ${ }^{3}$.

In contrast, we know relatively little about the risk management practices of market intermediaries. Theoretical modeling of the risk management problem faced by market intermediaries has been very recent (Froot and Stein, 1998). On the empirical side, microstructure researchers have shown how intermediaries charge a bid-ask spread to protect themselves against adverse selection risk and individual asset inventory risk, and how dealers manage the specific risk implicit in their individual asset inventories. However, we do not as yet know much about how intermediaries manage the hedgeable market risk component of their core business risk, and the role that derivatives contracts play in this risk management ${ }^{4}$. In particular, we do not know the extent to which intermediaries engage in selective market risk-taking. We also do not know whether, and to what extent, market

\footnotetext{
${ }^{1}$ Metallgesellschaft, Orange County, and Proctor and Gamble reported large losses as a result of trading in derivatives while Daimler Benz reported large losses for not using derivatives to hedge its dollar receivables.

${ }^{2}$ See for example, Holthausen (1979), Anderson and Danthine (1981), Stulz (1984), Smith and Stulz (1985), Shapiro and Titman (1986), DeMarzo and Duffie (1991, 1995), Froot, Scharfstein and Stein (1993), Ljungqvist (1994), May (1995), Stulz (1996), Raposo (1996), Degeorge, Moselle and Zeckhauser (1996), Breeden and Viswanathan (1998), Mello and Parsons (2000) for risk management by firms or managers of firms.

${ }^{3}$ See Tufano and Serbin (1993), Tufano (1994), Tufano and Headley (1994a, b), and Haushalter (1997) for case studies on risk management. For empirical research, see, e.g., Booth, Smith and Stolz (1984), Block and Gallagher (1986), Wall, Pringle and McNulty (1990), Francis and Stephan (1990), Nance, Smith and Smithson (1993), Dolde (1993, 1995), Mian (1996), Tufano (1996), Hogan and Rossi (1997), Peterson and Thiagarajan (1997), Geczy, Minton and Schrand (1997, 1999), Allayannis and Ofek (1997), Haushalter (1997), Schrand and Unal (1998), Henschel and Kothari (1998), Guay (1998), Whidbee and Wohar (1999), Lynch Kosky and Pontiff (1999), Graham and Smith (1999), Graham and Rogers (2000) and Guay and Kothari (2001).

${ }^{4}$ There exists literature on hedging with futures contracts in the US government bond market (see, e.g., Kane and Marcus (1986), Hemler (1990) and Barnhill 1990). However, the focus of our work is very different.
} 
quality is affected by this selective market risk-taking in the wake of capital constraints.

Our paper contributes to the literature in three important ways. First, it analyzes how bond dealers trade in futures markets to manage their spot market risk exposure. Second, it examines, in the context of capital adequacy constraints, the relationship between the dealers' selective market risktaking activity and market quality. Finally, it investigates how market risk gets shared between dealers within a decentralised trading structure that has limited transparency. We conduct our investigation using a comprehensive dataset provided by the Bank of England. The data include the daily close-ofbusiness positions (long or short) of individual UK government bond dealers in every UK government bond issue, and in related interest rate futures contracts. Using these data, we investigate three major issues of interest to academics, regulators, practitioners and investors at large.

First, we investigate how financial intermediaries use futures markets to manage the hedgeable market risk component of their core business risk, namely, interest rate risk. This question is of considerable interest to academics because there exist two different views in the literature about the extent and type of risks that intermediaries carry on their books. Froot and Stein (1998) argue that financial intermediaries should fully hedge their exposure to any efficiently tradeable risk, while Stulz (1996) contends that some firms potentially have a comparative advantage in bearing certain risks, and they should exploit this comparative advantage by engaging in selective risk taking. The implications are different because the assumptions are different. Froot and Stein (1998) assume that intermediaries do not enjoy any informational advantage over other market participants. This is unlikely to be the case for dealer firms in bond markets since these firms see a large part of the order flow and the empirical market microstructure literature suggests that order flow is informative ${ }^{5}$. Therefore we should find that bond dealers exploit their information through selective market risktaking by following a duration targeting policy. We should also find that dealers who execute a greater proportion of order flow carry a greater amount of risk on their books and profit more from their informational advantage. Finally we should find that dealers' risk management decisions depend

\footnotetext{
5 See, e.g., Easely and O’Hara (1987), Barclay and Warner (1993), Lyons (1995), Keim and Madhavan (1996),
} 
on economic factors such as uncertainty in the market place, mispricing in futures markets, and the likelihood of regulatory distress through breach of capital adequacy requirements.

Second, we investigate whether dealers' selective market risk-taking policy affects their ability to provide liquidity to investors and therefore affects market quality, an issue of significant interest to academics and regulators. If dealers follow a duration targeting policy, then a part of their limited capital gets allocated to bearing hedgeable risk, risk that could have been laid off using futures contracts. This effectively reduces the amount of capital available for bearing security specific risk and providing liquidity to public investors. This, according to Froot and Stein (1998), should affect the prices at which dealers will be ready to execute trades. Clearly, the greater the extent of duration targeting, the lower will be the amount of capital available for providing liquidity to investors, and worse will be the prices offered to trades that make demands on dealers' capital. Therefore, we investigate if dealers' selective risk taking activity significantly affects market quality.

Finally, we examine whether overall market risk gets shared efficiently in a competitive dealership market that is not fully transparent, an issue of considerable interest to academics and regulators. Theoretical models of competitive dealership markets like Ho and Stoll (1983) and Biais (1993) show that public buy (sell) orders get best prices when they are executed by dealers with longest (shortest) inventory positions. Like the foreign exchange market, the US Treasury bond market and various over-the-counter markets, the UK government bond market has limited pre-trade transperency since there is no central quote posting facility or a consolidated limit order book. As a result, investors can encounter considerable search costs while finding the dealer offering the best price, i.e., the dealer with extreme exposure. Our data provides an opportunity to investigate how liquidity provision and market risk sharing takes place in these semi-transparent markets.

We find that dealers engage extensively in selective market risk-taking through duration targeting. The size of their futures position is comparable in magnitude to their spot position and their futures position usually reinforces the risk of their spot position. However, interestingly, we find that 
the dealers actively use futures contracts to offset or hedge changes in their spot position. This offset is partial in most cases. We also find that dealers use futures markets to a greater extent when the cost of hedging is lower, when the likelihood of regulatory distress (through breach of capital adequacy requirements) is greater, and during periods of greater economic uncertainty.

We find that dealers with higher turnover engage in greater amount of selective market risktaking and hedge changes in their spot exposure relatively less when compared with dealers with smaller turnover. This behaviour supports Stulz (1996) in as much as dealers with higher turnover see a greater proportion of the order flow and arguably have, or think they have, a greater comparative informational advantage relative to dealers with smaller turnover. However, we find that dealers with higher turnover do not earn profits from their selective risk-taking that are significantly greater than the profits of dealers with smaller turnover. This suggests that UK government bond markets are efficient, and the order flow related informational advantage of bond dealers is more perceived than real.

We also find that the fact that dealers do not fully hedge their market risk through derivatives affects market quality when dealers' selective market risk exposure is of substantial magnitude. We find asymmetric price effects. Trades that worsen (relax) dealers' capital adequacy constraints experience significantly worse (better) prices. This finding strongly supports Froot and Stein's (1998) argument about the price effects of capital adequacy constraints. Regulators interested in market quality should be concerned about this (asymmetric) adverse effect of dealers selectively taking on market risk that they could have hedged efficiently through the futures market.

Finally, in terms of efficient allocation of market risk among themselves, we find that dealers with extreme total risk exposures do absorb a greater amount of risk. However, this is driven by their trading in the futures market and not by their trading in the spot market. In the spot market, we do not find any evidence that dealers with relatively long (short) total risk position sell (buy) a greater amount of spot risk. This finding also has important implications for regulators concerned about the quality of execution offered to public investors. We know from Ho and Stoll (1983) and Biais (1993) 
that the price a dealer charges to a buy or sell trade is monotone function of her risk exposure. Therefore, a public buy (sell) trade receives best price if it is executed by a dealer with the shortest (longest) exposure. To the extent that public trades are not executed by dealers with divergent exposures, those trades do not receive the best execution possible. This suggests that trading costs in the UK government bond market (and potentially other markets with similar trading structure) can be lowered if public investors can be matched more effectively with dealers carrying extreme exposures. Therefore, regulators concerned about quality of execution in competitive dealership markets should consider market reforms that increase pre-trade transperency and thereby enable a better matching of public investors (liquidity demanders) and dealers with divergent inventories (most suitable liquidity suppliers). Examples of such reform are the introduction of a central quote posting facility or a consolidated limit order book. This will reduce trading costs and improve risk sharing and liquidity provision in these markets.

To summarise, our paper complements and contributes to the existing literature on risk management by examining for the first time three important issues. The first issue is how intermediaries manage the (hedgeable) market risk component of their core business risk with derivatives. Unlike the case of thrifts analysed in the literature, interest rate risk represents the core business risk of bond dealers, and our data help quantify precisely the amount of hedgeable core business risk financial intermediaries carry on their books and measure the profits arising from their selective market risk-taking activity. The second issue is the relation between intermediaries' selective risk-taking activity and market quality in the context of capital adequacy constraints. And the third issue is the efficiency of risk-sharing in decentralized and semi-transparent financial markets. In the context of all of these, it is important to note that our paper analyses the risk management practices of sophisticated market professionals who, compared to managers of traditional firms, are in a better position to understand and manage their risk. This is because they are exposed to a single source of risk, namely, interest rate risk, and there exist highly liquid futures markets that enable efficient management of that risk. 
The rest of the paper is organized as follows. Section I describes the salient features of the UK Government bond market and the data analyzed in this paper. Section II outlines the measures used for analyzing the risk exposure of spot and derivative positions. Section III provides a descriptive analysis of risk exposures of and profits made by different bond dealers. Section IV examines how intermediaries manage their spot risk with derivatives. Section V investigates the selective risk taking and hedging behavior of higher turnover dealers (who arguably enjoy comparative advantage due to order flow information) relative to lower turnover dealers. Section VI examines price effects of capital adequacy constraints and the relationship between intermediary risk taking and market quality. Section VII investigates how risk gets shared and liquidity is provided in semi-transparent markets. Section VIII offers concluding remarks.

\section{The Data and the Salient Features of the UK Government Bond Market}

Our sample period runs from August 1994 to December 1995. In August 1994, there were ninety different issues of gilts with a nominal outstanding value of $£ 205$ billion (see Appendix A for details) ${ }^{6}$. Trading in these UK government bonds is organised on the London Stock Exchange in a competitive dealership environment with several dealer firms competing with each other to execute the public order flow ${ }^{7}$. During our sample period, the dealer firms were required to be independent legal entities separately capitalised from the parent firm. They also had to register themselves with the Bank of England, the supervising regulatory authority and were required to report to the Bank every day their close-of-business inventory position in each government bond issue and in related derivatives contracts. Our data consists of the daily close-of-business reports filed by the dealer firms from August 1, 1994 to December 30, 1995 (358 business days). It provides individual dealer's inventory positions in each bond issue (number of bonds and whether long or short) and in related

\footnotetext{
${ }^{6}$ The London Stock Exchange Quarterly reports that in 1994, the total turnover in UK government bonds was $£ 1,545$ billion in about 700,000 trades, corresponding to an average trade size of $£ 2.2$ million. However, the median trade size was much smaller, less than $£ 100,000$. During our sample period, there was no Strips market or Repo market in the UK Government bonds. These developments took place in 1996-97.

${ }^{7}$ See Proudman (1995), Vitale (1998) and Hansch and Saporta (1999) for microstructural details of the UK
} 
futures contracts (number of futures contracts and whether long or short). We analyse the close-ofbusiness reports of fifteen dealer firms (see Appendix B for relevant financial details of twelve of these dealer firms). Out of our fifteen dealers, five dealers report positions in seventy or more bonds, six dealers between fifty to seventy bonds and remaining four dealers in less than fifty bonds. All dealers report positions in long-term bond futures contract (called the long-gilt futures contract) traded on LIFFE - the London International Financial Futures Exchange. These positions are typically in the nearest maturity contract, rolled forward to the next maturity contract in the expiry month. Occasionally, some dealers report small positions in the three-month LIBOR interest rate futures contract. However, more than $99 \%$ of their futures risk exposure comes from positions in the long-gilt futures contracts ${ }^{8}$.

In figures IA and IB, we plot snapshots of the zero coupon yield curves for UK Government bonds at six-monthly intervals from January 1993 to January 1996. This provides a picture of the interest rate volatility in the UK government bond market immediately before and during our sample period. It is evident that there were large shifts in the term structure before the start of the sample period (Figure I.A) when interest rates at the long end first fell by about 250 basis points from January 1993 to January 1994 and then rose again by about 125 basis points up to July 1994 . Over the sample period itself (Figure I.B), the long end remained virtually unchanged and there has been some, but not excessive, volatility in the medium maturity term structure range.

\section{Measures of Systematic Risk Exposure}

We compute the systematic risk of a dealer's bond portfolio using a theoretical measure and an empirical measure. We use the modified Macaulay duration of a bond as our theoretical measure of its systematic risk while we use the number of futures contracts one needs to trade in order to hedge

\footnotetext{
government bond market.

${ }^{8}$ No dealer reports any positions in options on interest rate futures contracts. The annual reports of the dealer firms do not also report any options' positions. This may be because during our sample period, the options market in London was relatively illiquid and not very deep. In particular, the average net exposure corresponding to the total open interest in option contracts on Long Gilt Futures was of the order of $2 \%$ to $3 \%$ of
} 
that bond as our empirical measure of its systematic risk ${ }^{9}$.

\section{A. Theoretical Measure of Risk Exposure}

We compute the modified Macaulay duration (henceforth, simply referred to as duration) $D_{i, t}$ at time $t$ of bond $i(i=1, \ldots, 90$ in our sample) maturing at time $T$ as:

$$
D_{i, t}=\frac{1}{P_{i, t}} \sum_{s=1}^{T} \frac{s C_{i, t+s}}{\left(1+y_{i, t}\right)^{s+1}}
$$

where

$P_{i, t}$ is the market price of bond $i$ at time $t ; C_{i, t+s}$ is the cash flow received from bond $i, s$ periods after time $t$; and $y_{i, t}$ is the yield to maturity on bond $i$ at time $t$.

We measure the theoretical (duration based) Spot Exposure of dealer $k$ as at the end of day $t$ as

$$
S_{k, t}=\sum_{i=1}^{90} \frac{V_{i, t}^{k} D_{i, t}}{100}
$$

where

$V_{i, t}^{k}$ is the Pound Sterling value of the position (duly signed) of dealer $k$ in bond $i$ at the end of day $t$ and $D_{i, t}$ is the Duration of bond $i$ as defined in equation (1) above.

Similarly, we measure theoretical (duration based) Futures Exposure of dealer $k$ at the end of day $t$ as

$$
F_{k, t}=\sum_{j=1}^{J} \frac{W_{j, t}^{k} D_{j, t}}{100}
$$

where $W_{j, t}^{k}$ is the Pound Sterling value of the position (duly signed) of dealer $k$ in futures contract $j$ at the end of day $t$; and $D_{j, t}$ is the duration of the futures contract (based on the cheapest-to-deliver bond) at the end of day $t$.

\section{B. $\quad$ Empirical Measure of Risk Exposure}

the average net exposure corresponding to the total open interest in Long Gilt Futures contracts.

${ }^{9}$ Arguably, there exist systematic risk factors other than duration in the bond markets. Chaumenton et al (1996) examine the relative explanatory power of different risk factors in the UK government bond market. They find that (see their Table 3) the second factor adds an extra 3.4\% explanatory power over the $86.4 \%$ provided by 
Our empirical measure of the systematic risk of a bond is based on the number of Long Gilt futures contracts one needs to trade in order to hedge the systematic (or hedgeable) risk of a bond position. We use the "beta" of a bond vis-à-vis the Long Gilt Futures contract as our empirical measure of the systematic risk of that bond. We estimate the risk $\beta_{i}$ of the bond by regressing the daily bond return on the daily return on a Long Gilt Futures contract. In particular, we run the following regression

$$
R_{i, t}=a_{i}+\beta_{i} R_{f, t}+\eta_{i, t}
$$

where $\quad R_{i, t}$ is the return on bond $i$ from day $t-1$ to day $t ; R_{f, t}$ is the return on the Long Gilt Futures contract from day $t-1$ to day $t$; and $\beta_{i}$ is the slope coefficient or the "beta" of that bond vis-à-vis the Long Gilt Futures contract.

We estimate the systematic (or hedgeable) risk of a bond on a rolling basis using price data over the previous three-month period $^{10}$. We denote the systematic risk of a bond $i$ on day $t$ by $\beta_{i, t}$ where the subscript $t$ denotes that a three-month period ending on day $t$ is used to estimate the risk of that bond as on day $t$. To make the empirical measure comparable with the theoretical measure and represent also the change in wealth corresponding to a $1 \%$ change in interest rates, we define the empirical measure as the duration of the cheapest-to-deliver bond for the futures contract, multiplied by the weighted average of the pound sterling value of the position held in different bonds, with the bond "betas" as the weights.

We define the empirical (beta based) Spot Exposure of dealer $k$ as at the end of day $t$ as

$$
S_{k, t}^{E}=\sum_{i=1}^{90} \frac{V_{i, t}^{k} \beta_{i, t} D_{j, t}}{100}
$$

where

$V_{i, t}^{k}$ is the Pound value of the position (duly signed) of dealer $k$ in bond $i$ at the end of day $t ; \beta_{i, t}$ is the systematic risk of bond $i$ on date $t$, and $D_{j, t}$ is the duration of the duration (i.e. Shift). Therefore, we select duration as our proxy for the systematic risk factor in our analyses.
${ }^{10}$ We adjust the beta estimate of illiquid bonds using the Cohen et al (1983) procedure. 
futures contract (based on the cheapest-to-deliver bond) at the end of day $t$.

Similarly, we define the empirical Futures Exposure of dealer $k$ at the end of day $t$ as

$$
F_{k, t}^{E}=\sum_{j=1}^{J} \frac{W_{j, t}^{k} D_{j, t}}{100}
$$

where

$W_{j, t}^{k}$ is the Pound Sterling value of the position (duly signed) of dealer $k$ in futures

contract $j$ at the end of day $t$, and $D_{j, t}$ is the duration of the futures contract (based on the cheapest-to-deliver bond) at the end of day $t$.

The theoretical measure differs from the empirical measure because the former weights bonds by their duration while the latter weights them by their beta vis-à-vis the Long Gilt futures contract. In a frictionless world in which duration captures all term structure risk, the two would be identical. However, if the factor representing rotation of the yield curve is important, or if some bonds are illiquid, then the beta of the bonds would be different from the ratio of their durations ${ }^{11}$. We find the average correlation between risk exposures of the fifteen dealers estimated by the two measures to be 0.92 for spot exposure and 0.85 for spot-plus-futures exposure.

\section{Descriptive Analyses of Spot and Futures Risk Exposure}

\section{A. $\quad$ Magnitude of Total (i.e. Spot-plus-Futures) Risk Exposures}

The first row of Table I describes the absolute value of the total (i.e., spot-plus-futures) risk exposures carried by the dealers overnight, using both the theoretical duration-based measure and the empirical beta-based measure. As the maximum to minimum range indicates, there is considerable variation in the average risk exposures across dealers. From a one percent change in interest rates, the biggest dealer stands to gain or lose about $£ 32$ Million ( $£ 26$ Million) while the smallest dealer stands to gain or loose about $£ 1.5$ Million ( $£ 1.3$ Million) by the theoretical (empirical) measure. The mean

\footnotetext{
${ }^{11}$ Figure 2 plots the beta versus the duration for the 90 bonds. As we can see, most of the bonds fall on a straight line, with beta values corresponding approximately to the values that we would expect on the basis of duration. About 7 or 8 bonds - all of them at the short end - are above the line, while about four times that number are below the line. Most of the bonds below the line are long maturity bonds, which are relatively illiquid. As a
} 
and median risk exposures across the dealers are $£ 12$ million ( $£ 10$ million) and $£ 10$ million ( $£ 8$ million) respectively using theoretical (empirical) measure ${ }^{12}$. The last column of Table II denoted as 'Overall' reports the information for the dealers as a group. We construct the 'Overall' position each day by aggregating the duly signed positions of each dealer in every bond issue and in every futures contract. The average total risk exposure carried by the dealers in the aggregate equals $£ 161$ Million ( $£ 134$ Million) using theoretical (empirical) measure ${ }^{13}$. Figures 3 and 4 plot the time series variation in the 'Overall' end of day total, i.e., spot-plus-futures, risk exposures of the dealers in aggregate. As can be seen, the dealers as a group engage in duration targeting in a big way and their target has been consistently negative during our sample period.

\section{B. $\quad$ Signed Values of Spot Exposure and Futures Exposure}

The second row of Table I describes the variation in the signed values of average spot exposures of the dealers. The average individual spot exposures is negative for an overwhelming majority of the dealers. It varies from -£28 million (-£22 million) to $£ 0.6$ million ( $£ 0.3$ million) using theoretical (empirical) measure. The mean, median and Overall spot risk exposures equal - $£ 6$ million (-£4 million), $-£ 3$ million (-£3 million) and $-£ 87$ million (-£61 million) respectively. Interestingly, the average signed futures exposure of dealers (see row three of Table I) are of same sign and of similar magnitude as the signed spot exposures. In particular, the average futures exposure varies from -£20 million (-£22 million) to $-£ 0.2$ million (-£0.2 million) using theoretical (empirical) measure. The mean, median and 'Overall' futures risk exposures respectively are $-£ 5$ million (- $£ 5$ million), $-£ 3$ million (-£3 million) and $-£ 74$ million (-£73 million).

result, our empirical measure is somewhat less in magnitude relative to our theoretical measure.

${ }^{12}$ Changes in interest rates on normal days are typically of the order of few basis points. The numbers appear high because they correspond to a one percent change in interest rates. These risk exposures can also be expressed in terms of the one-day $1 \%$ level Value-at-Risk (VAR) using average daily volatility of the long-gilt futures contract price of about $0.5 \%$. The average empirical exposures correspond to a one-day $1 \%$ level VAR of about $£ 6$ Million for the biggest dealer and about $£ 0.2$ dealer for the smallest dealer. As a fraction of the value of equity shareholders funds of the dealer firm, the average VAR (across all dealers, and all days of the sample period) equals $4.9 \%$ of their equity funds. This average VAR varies from $0.6 \%$ to $12.5 \%$ of the equity shareholders funds for different dealers.

${ }^{13}$ The minimum 'Overall' exposure is $£ 81$ million ( $£ 44$ million) while the maximum Overall exposure equals $£ 296$ million ( $£ 229$ million) during the sample period. These correspond to a VAR of $£ 22$ million on average, minimum of $£ 7$ million and maximum of $£ 38$ million. 
We shed further light on the similarities in the magnitude and the direction of average spot and futures exposures in several ways. We examine whether the dealers prefer to use one market over the other to achieve their duration target by computing the magnitude of futures exposure as a percentage of the magnitude of spot exposure plus the magnitude of the futures exposure for individual bond dealers. We find that (see Table I row 4) the average value of this fraction across dealers has a mean of $36 \%(42 \%)$ and a median of 33\% (43\%) percent with the theoretical (empirical) measure. At an 'Overall' level, this fraction has a mean of $47 \%(53 \%)$ and a median of $49 \%(55 \%)$. This suggests that the dealers rely on the spot market and futures markets more or less equally to achieve their target.

We examine whether futures exposure reinforces (or offsets) spot exposure by computing the spot-futures-offset ratio. Towards that end we divide a dealer's 'net total exposure' by her 'gross total exposure' at the end of each day, subtract the ratio from one and define it as the spot-futures-offset ratio $^{14}$. If futures position exposure reinforces (offsets) the spot position, then this ratio will approach $0 \%(100 \%)$. We find that (see row five of Table I) the mean and median spot-futures-offset ratio equals $27 \%(30 \%)$ and $19 \%(27 \%)$ using the theoretical (empirical) measure. The 'Overall' spotfutures-offset ratio equals $3 \%(5 \%)$. A great majority of the offset ratios are closer to zero percent than to one hundred percent. This confirms that the dealers achieve their duration target by taking futures positions that are generally in the same direction as their spot position.

In figures 3 and 4 , the futures exposure appears to vary in a direction opposite to that of the spot exposure. Therefore, we also examine how the deviation of a dealer's spot exposure from its sample mean relates to the deviation of her futures exposure from its sample mean. Towards that end, we also measure dealers' demeaned spot-futures-offset ratio. We find that (see row six of Table I) the mean and median spot-futures-offset ratio equals $40 \%(44 \%)$ and $36 \%(44 \%)$ using the theoretical (empirical) measure. The 'Overall' spot-futures-offset ratio equals 50\% (58\%). When we measure the

\footnotetext{
${ }^{14}$ For example, suppose a dealer's spot exposure and future exposures at the end of a day equal $£ 4$ Million and -£2 Million respectively. Then, her net total exposure is $£ 2$ Million, her gross total exposure is $£ 6$ Million and her spot-futures offsetting equals $1-\{|2| /|6|\}=0.667$ or $66.7 \%$.
} 
percentage of days when the demeaned spot and futures exposures are of opposite sign, we find that (see row seven of Table I) the mean and median percentage equals 68\% (71\%) and 69\% (76\%) using the theoretical (empirical) measure. The offsetting in direction of demeaned spot and demeaned futures equals $72 \%$ (79\%) for the 'Overall'. This suggests that, in general, when a dealer's spot exposure is above its sample mean, her futures exposure is below its sample mean and vice-versa.

These results highlight three important things. First, the dealers engage extensively in duration targeting. Second, they achieve their duration target by taking a position in futures market that are of similar order of magnitude and usually in the same direction as their spot position. Finally, dealers actively manage the deviation from their duration target by varying their futures exposure in such a way that it offsets the changes in their spot exposure.

\section{C. $\quad$ Profitability of Overnight Risk Taking}

We measure the profit made by the dealers from their selective market risk-taking activity by expressing the total empirical risk exposure carried by a dealer at the end of day $t$ in terms of the number of futures contracts, and multiplying it by the change in the price of the futures contract from the close of day $t$ to the open of day $t+1$. This product represents the profit arising from dealers' decisions to carry the risk on their books overnight. We report the average daily profits of dealers in the bottom panel of Table I. We find that the average daily profit across the dealers has a mean (median) of $-£ 2,600(-£ 3,000)$. The dealers collectively make an average daily profit of $£ 22,000$ and individually it varies from a profit of $£ 40,000$ per day to a loss of $£ 54,000$ per day across the fifteen dealers. Since the profit can also be expressed in terms of the return earned by dealers from their risktaking activity, we report their profit per unit of risk carried overnight. The average scaled profit is simply the overnight return on the futures contract weighted by the risk carried each night expressed in terms of equivalent number of futures contracts. We find that the average daily scaled profit across the dealers has a mean (median) of -1.3 basis points ( -4.5 basis points) and it varies from a profit of 25 basis points per day to a loss of 40 basis points per day across the fifteen dealers ${ }^{15}$.

15 Looking at the financial statements in Appendix B, one may wonder as to why so many sophisticated 


\section{Risk Management with Futures}

One way to understand the duration targeting behaviour of dealers is to examine the mean reversion in their total (spot-plus-futures) risk exposure. If dealers actively control the deviations from their duration target, then we should find significant mean reversion in their total risk exposure. Towards that end, we run the following regression for each dealer

$$
\Delta\left(S_{k, t}+F_{k, t}\right)=\alpha_{k}+\gamma_{k}\left(S_{k, t}+F_{k, t}\right)+\varepsilon_{k, t}
$$

where $S_{k, t}$ is dealer $k$ 's spot risk exposure at the end of day $t, F_{k, t}$ is dealer $k$ 's futures risk exposure at the end of day $t$, and $\Delta\left(S_{k, t}+F_{k, t}\right)$ is the change in dealer $k$ 's total risk exposure from day $t$ to day $t+1$, measured as dealer $k$ 's total exposure at the end of day $t+1$ minus her total exposure at the end of day $t$. A negative and significant $\gamma_{k}$ implies that dealers actively manage their total risk exposure.

Table II reports the results of the regression using the theoretical and empirical measures of risk exposures. For the purpose of reporting, we rank the dealers in decreasing order of their average magnitude of overnight total (spot-plus-futures) exposures using the theoretical measure. We find that the total risk exposure of fourteen (fourteen) out of fifteen dealers shows significant mean reversion using the theoretical (empirical) measure at the ten percent level. Their mean reversion coefficients vary from -0.03 to $-0.20(-0.03$ to -0.36$)$ using the theoretical (empirical) measure. These correspond to inventory half-lives ranging from 3 days to 36 days (2 days to 28 days).

The results in Table I and II confirm that during our sample period the dealers had a duration target that was negative, and they actively controlled the variance around this target. In order to better

financial institutions have loss-making subsidiaries in this industry. In this context, it is important to mention that the parent firms listed in Appendix B also have motives other than profit to create these dealer subsidiaries. These dealer firms can provide useful service to the proprietary trading arm or the arbitrage trading desk of the parent firm. For example, first, the dealer firms can execute large trades for the parent without leaving much of a foot-print that can enable other market participants to infer the information content of the trade. Second, the dealer firms can borrow stock and engage in short-selling, otherwise difficult in the UK even for institutions. Third, dealer firms are exempt from paying stamp duty for its own trades, which can be useful in the context of short-term arbitrage trading strategies. Finally, dealer firms have preferential access to new bond issues. Our findings relating to profitability suggests that these other motives for creating dealer subsidiaries may be more 
understand how dealers control the variation in their risk exposure, we examine the relationship between the change in a dealer's spot exposure and the change in that dealer's futures exposure. Towards that end, we regress the daily change in a dealer's futures risk exposure on the contemporaneous and lagged daily change in her spot exposure ${ }^{16}$. In particular we run the following regression for each dealer

$$
\Delta F_{k, t}=a_{k}+h_{k} \Delta S_{k, t}+h_{k, l} \Delta S_{k, t-1}+e_{k, t}
$$

where $\Delta F_{k, t}$ is the change in Futures Exposure of dealer $k$ from end of day $t$ to end of day $t+1, \Delta S_{k, t}$ is the change in Spot Exposure of dealer $k$ from end of day $t$ to end of day $t+1, \Delta S_{k, t-1}$ is lagged change in Spot Exposure of dealer $k$ (from end of day $t-l$ to end of day $t$ ), $h_{k}$ and $h_{k, l}$ are contemporaneous and lagged 'hedge' ratios, and $a_{k}$ and $e_{k, t}$ are the intercept and error terms respectively. It is important to note that our use of the word 'hedge' ratio is not just for simplicity of exposition. Given the fact that interest rate risk represents the dealers' core business risk, and the fact that they engage extensively in selective risk-taking, the economic consequences of hedging are measured by the extent to which the dealers offset the changes in their spot exposure by actively changing their futures exposure.

We report the results of regression in equation (8) in Table III. We find that contemporaneous hedge ratio $h_{k}$ is significantly negative for each and every dealer and varies from -0.20 to $-0.80(-0.23$ to -1.06 ) using the theoretical (empirical) measure. The lagged hedge ratio $h_{k, l}$ is negative and significant in case of seven (five) dealers with the theoretical (empirical) measure, and in these cases, the magnitude of the lagged hedge ratio is about one-third to one-ninth of $h_{k}$. The R-squares of the regressions for most of the dealers are also high, indicating the economic significance of the relation

\footnotetext{
important for these parent firms.

${ }^{16}$ We include lagged changes in the spot exposure for several reasons. The dealer may trade with the public or other dealers towards the end of the day or after the futures market has closed. The dealer's risk management actions would then only be observed on the next day. Also, when a dealer receives an order flow, it consists of liquidity-based component and information-based component. Since, the dealer is not able to distinguish these two components, she may decide to wait before deciding how much of the change in spot exposure needs to be hedged through the futures market.
} 
between changes in the spot and the futures exposures. Overall, these findings indicate that the dealers actively use futures markets to offset the changes in their spot risk and thereby control the variance around their duration target.

The regression in equation (8) measures average hedge ratios. Arguably, there exist factors that can potentially influence the extent to which dealers will use futures markets to hedge the deviations from their duration target. First, since dealers are risk averse, we should observe that the dealers hedge to a greater extent when the volatility of bond market is higher. Second, the risk of regulatory distress is greater when the level of spot exposure is relatively high and when the change in spot exposure is in a direction that increases the magnitude of this exposure. Therefore, we should observe higher hedge ratio on days when the risk of regulatory distress is greater. Third, as argued by Stulz (1984), costs should play an important role in the dealers' decision to use futures markets. A major cost faced by the users of futures markets is the predictable change in futures mispricing over time $^{17}$. Short hedges established with underpriced futures, and long hedges established with overpriced futures, are relatively costly and vice-versa. Clearly, dealers will have a lesser (greater) incentive to use futures markets to hedge in time periods when hedging is costlier (cheaper). Finally, there exist several macroeconomic variables (such as the $\mathrm{M}_{0}$ and the $\mathrm{M}_{4}$ measures of money supply, and the retail price index) that potentially affect the prices of government bonds. These macroeconomic variables are announced on a monthly basis, the date and time of which are well known ${ }^{18}$. One would expect that the perceived information asymmetry would be relatively high (low) before (after) these announcements, and therefore, that the dealers hedge more (less) during periods of high (low) perceived information asymmetry.

In view of these arguments, we examine whether dealers hedge the changes in their spot exposure relatively more (i) when the bond market volatility is greater; (ii) when the risk of regulatory

\footnotetext{
${ }^{17}$ Mispricing is defined as the difference between the actual futures price and its fair value calculated from the cost of carry model. LIFFE data provides both these numbers, details of the cheapest to deliver bond, etc.

${ }^{18}$ For example, during the sample period the Bank of England announced the provisional money supply $\mathrm{M}_{0}$ estimates three working days after the final Wednesday in the month while it announced the provisional $\mathrm{M}_{4}$ estimates on fourteenth working day after the last day of the month.
} 
distress (through breach of capital adequacy requirements) is higher; (iii) when hedging requires buying (selling) underpriced (overpriced) futures, and (iv) prior to important macroeconomic announcements ${ }^{19}$, and vice-versa. We examine this by running the following regression

$$
\begin{aligned}
\Delta F_{k, t}= & \gamma_{0}+\Sigma D_{k, t}\left(h_{k} \Delta S_{k, t}+h_{k, l} \Delta S_{k, t-1}\right) \\
& +\left(\gamma_{1} V_{o} l_{t}+\gamma_{2} S_{k, t-1}^{S t d}+\gamma_{3} \Delta S_{k, t-1}^{S t d}+\gamma_{4} D_{t}^{M i s p}+\gamma_{5} D_{t}^{A n n}+\gamma_{6} D_{t}^{d b A n n}\right) \Delta S_{k, t}+\omega_{k, t}
\end{aligned}
$$

where, $\Delta F_{k, t}, \Delta S_{k, t}, \Delta S_{k, t-1}, h_{k}$ and $h_{k, l}$ are same as in equation (8), $D_{k, t}$ is a dummy variable which takes the value 1 for observations corresponding to dealer $k, V_{o l} l_{t}$ is the standardized absolute value of the open-to-close price change of the near maturity long gilt futures contract, $S_{k, t-1}^{S t d}\left(\Delta S_{k, t-1}^{S t d}\right)$ is the standardized level (change in level) of dealer $k$ 's spot exposure as the end of day $t-1, D_{t}^{\text {Misp }}$ is a dummy variable which takes the value 1 when hedging requires buying (selling) underpriced (overpriced) futures and the value -1 when hedging requires selling (buying) underpriced (overpriced) futures, $D_{t}^{A n n}\left(D_{t}^{d b A n n}\right)$ is a dummy variable indicating if day $t$ was an announcement day (a day before an announcement day), $\gamma_{0}$ and $\omega_{k, t}$ are the intercept and error terms respectively.

Table IV reports results of regression (9) using both the theoretical and empirical measures of risk exposures. We find that, with both measures, the "normal" contemporaneous hedge ratios for dealers (the $h_{k}$ 's) continue to be negative and of the same order of magnitude as in Table III, and highly significant statistically in the case of 14 out of the 15 dealers (dealer 12 being the exception). The lagged hedge ratios continue to be negative, although for some dealers they lose their statistical significance. The slope coefficients on volatility, lagged level and lagged change in exposure, and future's mispricing variables $\left(\gamma_{1}\right.$ to $\left.\gamma_{4}\right)$ each come out negative and statistically significant at the $5 \%$ level with the theoretical measure. The results with the empirical measure are similar with the

\footnotetext{
${ }^{19}$ We consider $\mathrm{M}_{0}, \mathrm{M}_{4}$ and RPI (retail price index) announcements. Three announcements per month for seventeen months give us a total of fifty one announcements. These announcements, like most major announcements in the UK, are made at 09:30 hours. Almost all the trading on the day of announcements takes place after the announcement is made. This is captured by our day of announcement dummy.
} 
exception that the slope coefficient on volatility variable $\gamma_{1}$ remains negative but becomes statistically insignificant. With both measures we find the coefficient on the day of announcement dummy $\gamma_{5}$ is positive and significant while that on the day before announcement day dummy $\gamma_{6}$ is negative and significant ${ }^{20}$.

These results confirm that the dealers hedge to a greater extent when the potential costs of regulatory distress are higher and when the cost of hedging is lower. The results also confirm that dealers hedge relatively more in periods when the perceived information asymmetry is high, such as on days before major macroeconomic announcements. Once the announcement is made, the perceived information asymmetry is reduced and dealers seem to hedge relatively less. Finally, the dependence of the hedge ratio on bond market volatility is in the expected direction, but is significant only with theoretical measure.

\section{Comparative Informational Advantage of Dealers with Higher Turnover}

If order flow carries information (see, e.g., Easley et. al. (1997) and Ito et. al. (1998)), then dealers with relatively higher turnover would enjoy a comparative advantage over dealers with lower turnover. Then, according to Stulz (1996), we should find that higher turnover dealers (i) engage in greater selective risk taking (i.e. duration targeting), (ii) hedge to a lesser extent and (iii) profit more from their duration targeting activity as compared to lower turnover dealers. We investigate these cross-sectional implications in this section.

During our sample period, we obtain transactions audit trail data from the London Stock Exchange. The data identifies each trade by whether it was a buy or a sell trade and whether the dealer executes the trade on his own account or on behalf of a client. This enables us to compute the change in inventory of each dealer in each bond on each day of our sample period ${ }^{21}$. By comparing the

\footnotetext{
${ }^{20}$ There exists extensive market microstructure literature documenting day-of-the-week effects. Conceivably, these effects also exist in the government bond markets. Therefore, we also included the day-of-the-week dummies in the regression. We found none of the day of the week dummies were significant.

${ }^{21}$ We use the Hansch et al (1998) procedure to construct inventories of bond dealers. They use similar quality data for the equities traded on the London Stock Exchange.
} 
changes in inventories constructed from the transactions data with those reported in the Bank of England data, we obtain the turnover of each of our fifteen dealers during the sample period. We rank the dealers in decreasing order of their average daily turnover. We assign a "turnover rank" of one (fifteen) to the dealer with the highest (lowest) average daily turnover. We use this turnover rank as a proxy for a dealer's comparative informational advantage.

We measure the selective market risk-taking of dealers by the average magnitude of their overnight total risk exposure. We assign a "duration rank" of one (fifteen) to the dealer with the highest (lowest) average magnitude of overnight total (i.e. spot-plus-futures) risk exposure. Similarly, we rank the dealers in descending order of their hedge ratios $\left(h_{k}\right)$ reported in Table II and assign a "hedge ratio rank" of one (fifteen) to the dealer with the highest (lowest) hedge ratio. Since these hedge ratios are negative, the dealer with rank one (fifteen) offsets the changes in her spot exposure to the smallest (greatest) extent. Finally, we rank the dealers in descending order of their profits (reported in bottom panel of Table I). As before, we measure profitability in two ways, the average daily profits of a dealer; and average daily profits per unit of risk carried overnight by that dealer. We assign a "profit rank" of one (fifteen) to the dealer making the most (least) profit.

We regress the dealers' duration rank, hedge ratio rank and profit rank on their turnover rank. In particular, we run the following cross-sectional regressions across our fifteen dealers $(k=1,2, \ldots, 15)$.

$$
\begin{aligned}
\text { Duration Rank } & =c_{0}+c_{1} \text { Turnover } \operatorname{Rank}_{k}+f_{k} \\
\text { Hedge Ratio Rank } & =d_{0}+d_{1} \text { Turnover Rank } k_{k}+g_{k} \\
\text { Profit Rank }_{k} & =e_{0}+e_{1} \text { Turnover Rank } k_{k}+n_{k}
\end{aligned}
$$

We report the results in Table V. When we regress the dealers' duration rank on their turnover rank as per in equation (10a), we find $c_{1}$ to be 0.65 with a t-statistic of $3.08(0.73$ with a t-statistic of 3.88) with the theoretical (empirical) measure of risk. The adjusted R-square respectively equals $37.8 \%$ and $53.6 \%$. This suggests that, compared to the lower turnover dealers, the higher turnover dealers engage in selective risk taking to a significantly greater extent. This is consistent with higher turnover dealers perceiving themselves as having a comparative informational advantage over lower 
turnover dealers, and therefore engaging in selective risk taking to a greater extent.

When we regress the dealers' hedge ratio rank on their turnover rank as per equation (10b), we find that $d_{1}$ to be 0.60 with a t-statistic of 2.75 (0.59 with a t-statistic of 2.61) using the theoretical (empirical) measure of risk. The adjusted R-square respectively equals $31.8 \%$ and $29.3 \%$. This suggests that, compared to the lower turnover dealers, the higher turnover dealers hedge to a significantly lesser extent. This is once again consistent with the higher turnover dealers' perception of comparative informational advantage over lower turnover dealers.

Finally, when we regress the dealers' profit rank on their turnover rank as per equation (10c), we find $e_{1}$ to be -0.30 with a t-stat. of $-1.15(-0.28$ with a t-stat. of -1.06$)$ using the average daily profit (average daily profit per unit of risk) measure. The adjusted R-square respectively equals $2.2 \%$ and $0.9 \%$. This indicates the absence of any systematic relationship between the profitability from duration targeting activity and the fraction of order flow the dealers execute. In other words, we find that higher turnover dealers do not earn relatively greater profits from their duration targeting activity compared to lower turnover dealers. This finding is robust to measuring the profitability of risk taking using the theoretical measure instead of the empirical measure used above as well as measuring profitability in different ways. For example, instead of using close to the open (of next day) price change in the futures contract as profit, we measure it as close to close, or close to the best possible price next day (i.e., buying at the lowest price and selling at the highest price). Although the different measures change the level of profitability, the relationship between profitability and turnover ranking continues to remain statistically insignificant.

Overall these findings support Stulz's (1996) argument that firms engage in selective risk taking based on their perceived comparative informational advantage, though in this particular case, the comparative advantage is more perceived than real. The lack of significant relationship between turnover and profitability suggests that the UK government bond market is reasonably efficient, and observing a greater proportion of order flow does not impart higher turnover dealers a significant comparative advantage over lower turnover dealers. This is also consistent with the macro-economic 
(and hence public) nature of information in the government bond market, to which all dealers arguably have equal access.

\section{Selective Risk Taking and Market Quality: Price Effects of Capital Constraints}

In this section we examine the relation between dealers' selective market risk-taking and the market quality. Since the bond dealers engage in selective risk taking through duration targeting, a part of their capital gets allocated to bearing hedgeable risk. This reduces the amount of capital they have for providing liquidity to public investors. Froot and Stein (1998) argue that in the presence of capital constraints intermediaries will offer significantly worse (better) prices to trades that increase (reduce) the demand on their capital. This effect will be significant when their capital has been stretched to relatively extreme levels. We examine this pricing effect of capital adequacy constraints created by selective market risk-taking activity of the dealers. While conducting our investigation, we take into account relevant microstructure effects, for example, whether the public trades were buys or sells, and whether the trades were moving the dealers' exposure towards the sample mean or away from the sample mean.

The prices that dealers trade on are influenced by three factors. First, there are capital adequacy related considerations. These are expected to be important when the magnitude of dealers' total risk exposure is high. Second, there are inventory control considerations. These play an important role when the total risk exposure deviates substantially from the sample mean in either direction. Finally, it is known that dealers respond asymmetrically to public buy and sell trades in the equity market. For example, Keim and Madhavan (1996) find that dealer buy (i.e. public sell) trades taking place in the equities traded on the NYSE depress the price significantly. In contrast, dealer sell (i.e. public buy) trades do not lead to significant price effects. We do not know if a similar phenomenon occurs in bond markets as well. Nevertheless, we allow for this potentially asymmetric price impact of buy and sell trades in our investigation.

Figure 5 illustrates the essence of our investigation. It shows the evolution of total risk 
exposure of all dealers taken together during our sample period. As can be seen, the exposure is negative throughout and is mean-reverting around the sample mean. A and B (C and D) represent days when the overall total exposure is in top (bottom) decile. In the case of top-decile days (like A and $\mathrm{B}$ ) and the bottom-decile days (like $\mathrm{C}$ and $\mathrm{D}$ ), the deviation of the risk from the sample mean is of comparable order of magnitude. Therefore, from an inventory control point of view, one would expect dealers to treat these days symmetrically. However, this is not the case from a capital adequacy point of view. Capital adequacy considerations are unimportant on top decile days. However, they are of crucial importance on bottom decile days because on these days the magnitude of the exposure is very high. Therefore, on bottom-decile days, one expects the dealers to ask a significantly higher price while selling (as these trades make an additional demand on their capital) and to bid a significantly higher price while buying (as these trades help alleviate the capital adequacy constraints). We summarize these effects in Table VI.

We examine the price effects of selective market risk-taking activity of dealers by running the following regression

$$
\Delta P_{i, t}=\Sigma D_{i, t} D_{t}+\lambda_{B u y} D_{B u y} D_{i, t} \Delta I_{i, t}+\lambda_{\text {Sell }} D_{\text {Sell }} D_{i, t} \Delta I_{i, t}+\xi_{i, t}
$$

where $\Delta P_{i, t}$ is the change in the price of bond $i$ from end of day $t-l$ to day $t, D_{i, t}$ is duration of bond $i$ on day $t, D_{t}$ is a dummy representing the day of the sample period, $D_{B u y}$ and $D_{\text {Sell }}$ are dummies that take a value of one if the dealers have collectively bought or sold bond $i$ on day $t, \Delta I_{i, t}$ is the change in inventory of all dealers from end of day $t-1$ to day $t$, and $\lambda_{B u y}$ and $\lambda_{\text {Sell }}$ are the regression coefficients on change in inventory of the dealers.

Note that in the regression in equation (11) the term $D_{i, t} D_{t}$ controls for changes in prices of bonds due to changes in the term structure, while $\lambda_{B u y}$ and $\lambda_{\text {Sell }}$ represent the changes in bond prices due to changes in inventory risk exposures. $\lambda_{B u y}$ and $\lambda_{\text {Sell }}$ are indicators of market quality, where a "high quality" market is one in which in which the price is unaffected by the amount of liquidity 
demanded by public investors, i.e. $\lambda_{B u y}$ and $\lambda_{\text {Sell }}$ are zero. In the presence of limited market making capital, we expect $\lambda_{B u y}$ and $\lambda_{\text {Sell }}$ to be negative. This is because when dealers buy (sell) bonds, $\Delta I_{i, t}$ is positive (negative). This corresponds to selling (buying) pressure from the public, which causes the bond prices to fall (rise), thereby making $\lambda_{B u y}$ and $\lambda_{\text {Sell }}$ negative.

We implement the regression in equation (11) in the following way. We measure the inventory risk exposure (i.e. inventory value of the bond multiplied by its duration) of all dealers in each bond at the end of each day and standardize it by subtracting the sample mean and dividing it by the time series standard deviation. This makes inventory risk exposure comparable across bonds. For the same reason, we also measure the change in price of a bond in percentage terms. The slope coefficients $\lambda_{B u y}$ and $\lambda_{\text {Sell }}$ then measure the percentage change in price of a bond for one unit change in the collective inventory risk exposure of the dealers.

We rank the overall spot-plus-futures exposure at the end of each of the 358 days in descending order. We run the regression on days when the exposure lies in the top decile and in the botttom decile. We investigate whether the relative importance of capital adequacy constraints varies as the exposure moves away from the extreme by also running the regression in equation (10) for top quartile and bottom quartile days, and for above median and below median days ${ }^{22}$.

We report our findings in Table VII. Panel A reports the findings for the top decile and bottom decile days. For the top decile days, we find that the slope coefficient $\lambda_{B u y}$ is negative and statistically significant suggesting that dealers offer significantly lower prices while buying bonds on these days. This is consistent with the dealers' exposure moving away from the mean as well as the negative price impact expected of dealer buy (i.e. public sell) trades observed in equity markets. Interestingly, $\lambda_{\text {Sell }}$ is negative but not significant, suggesting that the dealers' desire to bring the

\footnotetext{
${ }^{22}$ The top and bottom decile analysis covers 35 days each (70 days in total), while the top and bottom quartile analysis covers 89 days each (198 days in total). The above median and below median analysis covers the entire sample period (356 days).
} 
exposure towards the mean is not strong enough to translate itself into significant price effects.

In contrast, on bottom decile days (second row of Panel A), the slope coefficient $\lambda_{B u y}$ is positive and statistically significant. These trades alleviate capital adequacy constraints as well as bring the dealers exposure towards the mean. However, we know that $\lambda_{\text {Sell }}$ is indistinguishable from zero on top decile days suggesting that the desire to mean revert does not translate itself into significant price effects. Therefore, the positive and significant $\lambda_{B u y}$ on bottom decile days must be driven by the alleviation of capital adequacy constraints, the effect of which is strong enough to overcome any negative price impact the dealer buy (i.e. public sell) trades may have. Furthermore, on bottom decile days we find $\lambda_{\text {Sell }}$ to be negative and significant at the ten percent level. This is consistent with worsening of capital adequacy constraints as well as these trades taking the dealers away from the mean. If one were to assume that the price effects of moving the exposure towards the mean or away from the mean are symmetric, then the negative and significant $\lambda_{\text {sell }}$ must be due to worsening of capital adequacy constraint effect created by dealers' selective market risk-taking activity. This is because we know from the top decile results that dealer sell trades that bring exposure towards the mean do not have significant price effects. These findings confirm that dealers market risk-taking activity affects market quality, especially when the hedgeable risk exposure carried by dealers is at extreme levels.

In order to examine the robustness of these findings, we also run the regression for top quartile and bottom quartile days and report the findings in Table VII-Panel B. We find results that are consistent with the top decile and bottom decile days reported in Panel A. On top quartile days, $\lambda_{B u y}$ is negative and statistically significant at ten percent level while $\lambda_{\text {Sell }}$ is insignificant. On bottom quartile days, $\lambda_{B u y}$ is positive and statistically significant at ten percent level. The only difference being that $\lambda_{\text {Sell }}$ now looses its statistical significance on bottom quartile days. Overall, the results are qualitatively similar to that found with the extreme decile analysis with the magnitude of the slope 
coefficients being somewhat reduced. This is to be expected since the quartile based analysis also includes days where the deviation from the mean is not as extreme as in case of extreme deciles. Therefore, on average, one expects the capital adequacy constraints to be less binding. The findings from above median and below median analysis (see Table VII-Panel C) are once again qualitatively similar in terms of the magnitude and direction of slope coefficients with the statistical significance getting further reduced as we include all days.

On the whole, the findings in Table VI strongly support the price effects of capital constraints argued for by Froot and Stein (1998). These effects are the strongest when the constraints are most binding, i.e., when dealers are carrying a large amount of hedgeable risk on their books, risk that could have been laid off in futures markets. Regulators concerned about market quality should take notice of the adverse asymmetric price effects of dealers' selective risk-taking activity.

\section{Liquidity Provision and Risk Sharing in Semi-transperent Markets}

In this section, we investigate how the liquidity demanded by investors is provided by dealers carrying differing risk exposures. In the theoretical models of competitive dealership markets, like Ho and Stoll (1983) or Biais (1993), a dealer's keenness to buy or sell is a monotone function of her inventory - the source of her risk exposure. Therefore, an investor gets the best deal if his buy (sell) trade is executed by the dealer with the longest (shortest) exposure. Unfortunately, in the absence of full pre-trade transperency, (e.g. through a central quote posting facility or a consolidated limit order book) this is difficult to achieve. An investor wishing to trade needs to call and negotiate with dealers one by one before he can find the best price. Clearly, this involves considerable search costs and it is likely that a public trade is not always executed by the dealer with the extreme exposure. As a result, the investor may end up paying more for a buy trade or receive less for a sell trade. This is a matter of concern for regulators whose objective is to minimize investors' trading costs.

We use the monotone relationship between the level of exposure and reservation quotes from the theoretical models to draw inference about the quality of execution received by investors in the 
UK government bond market. In particular, we examine whether dealers with relatively long (short) exposure sell (buy) a larger proportion of exposure or not. To operationalise empirical examination of this issue, one needs to take account of the fact that dealers' risk exposures cannot be compared against each other directly. This is because dealers have different duration targets and they differ in terms of their capitalization or risk aversion. In the presence of duration targeting, what matters in the dealer's decision function is not the level of her risk exposure, but the deviation of her risk exposure from the duration target. Also, differences in capitalization or risk aversion imply that a trade of a given size will be perceived differently by different dealers. We address these issues by standardizing the risk exposure of each dealer (i.e. by subtracting the mean and dividing by the standard deviation). Subtracting the mean adjusts for differences in duration targets, and dividing by the standard deviation enables comparability across firms ${ }^{23}$. When working with standardized exposures, one can expect that a dealer with relatively long (short) exposure, sells (buys) to a greater extent compared to the dealer with the median level of exposure. One can also expect that the greater the exposure of a dealer, the larger will be the quantity she will be selling and vice-versa.

We investigate these theoretical predictions in the following way. At the end of each day we measure the total (i.e. spot-plus-futures) exposure of each dealer $S_{k, t}+F_{k, t}(k=1,2, \ldots 15)$ and arrange it in descending order. We assign the dealer with largest (smallest) total exposure an exposure-levelrank of one (fifteen). Next, we compute $\Delta\left(S_{k, t+1}+F_{k, t+1}\right)$ - the change in the total exposure of each dealer over the next day, and rank them so that the dealer who sells the most (least) exposure gets change-in-total-exposure rank of one (fifteen). We repeat this exercise for each day in the sample ${ }^{24}$. If the implications of the theoretical models hold in practice, then a dealer with low exposure-level-rank

\footnotetext{
${ }^{23}$ Hansch et al (1998), and Naik and Yadav (1999) use a similar procedure while examining the trading behavior of dealers in the equity market. Standardization controls for differences in capitalization or risk aversion if it is assumed that different dealers perceive risk in a similar way when their exposure is measured in terms of the distance in standard deviations from the duration targets. For expositional convenience, we hereafter drop the descriptor standardized unless needed for clarity

${ }^{24}$ Note that as the risk exposure of a dealer changes relative to her competitors from one day to another, she receives a different exposure-level rank and a different change-in-exposure rank. In this section we examine the relationship between the average change-in-exposure rank of dealers who had the same exposure-level rank the
} 
would have a low change-in-exposure rank (i.e. a dealer carrying a greater amount of exposure would be selling a larger amount of exposure the next day) and vice-versa. We examine the relation between the level-exposure rank at the end of a day and the change-in-total-exposure rank, the change-in-spotexposure rank and the change-in-futures-exposure rank over the next day.

In particular, we run the following regression with the dependent variable being the average rank based on change-in-exposure (either total-exposure or spot-exposure or futures-exposure) and the independent variable being the end-of-day total exposure rank.

$$
\text { Average_Change_in_Exposure Rank } k_{l}=m_{0}+m_{1} \text { Exposure_level Rank } k_{l}+m_{l}
$$

where $l=1,2, \ldots, 15$ represents the rank of the dealer depending on her end-of-day total exposure and change in respective exposure (total, spot or futures) over the next day.

We report the results of our investigation in Table VIII and Figure 6. For expositional convenience, we subtract the median rank from all change-in exposure-ranks and report them as deviation from the median rank. We find that as far as change-in-total-exposure is concerned (see Table VIII-Panel A), the findings are highly consistent with the implications of the theoretical models. Dealers with top five (bottom five) exposure levels show a change in total exposure that is statistically significantly greater (smaller) than the median dealer. The regression of change-in-total-exposure rank on the exposure-level-rank provides a slope coefficient of -0.18 with a t-stat. of -13.97 , and an adjusted R-square of 93 percent. The regression confirms that dealers with relatively long standardized exposure sell a greater standardized exposure the next day, and vice-versa. This finding is illustrated in Figure 6-Panel A.

The findings with changes in futures exposure are qualitatively similar (see Table VIII-Panel B). Dealers with top four (bottom two) exposure levels show a change in futures exposure that is statistically significantly greater (smaller) than the median dealer. The regression of change-infutures-exposure rank on the exposure-level-rank provides a slope coefficient of -0.10 with a tstatistic of -10.19 , and an adjusted R-square of 88 percent. The regression confirms that dealers with 
relatively long standardized exposure sell greater standardized exposure in the futures market the next day, and vice-versa. This relationship is depicted in Figure 6-Panel B.

However, there is virtually no relationship between the end-of-day-total-exposure and the change-in-spot-exposure (see Table VIII-Panel C). Eleven dealers exhibit a change in spot exposure that is indistinguishable from that of the median dealer, and the dealers that exhibit a change in spot exposure that is statistically significantly greater (smaller) than the median dealer, are not those with extreme ranks (level rank of four, eight, thirteen and fourteen). The regression of change-in-spotexposure rank on the exposure-level-rank provides a slope coefficient of -0.02 with a t-statistic of 0.84 , and an adjusted R-square of minus two percent. In other words, dealers with relatively long standardized exposure do not necessarily sell greater standardized exposure in the spot market the next day, and vice-versa. This is visually highlighted in Figure 6-Panel C.

The sharp contrast between the results in Panels B and C of Table VIII and of Figure 6 indicates the following. Dealers actively control their total standardized risk exposure. Whenever their standardized exposure becomes long relative to that of the median dealer, they offload a part of it and vice-versa. However, they seem to rely on the futures market (which is highly transparent and efficient) to achieve this rather than the spot market (which has limited transparency).

The findings in Table VIII-Panel $\mathrm{C}$ have important implications for the regulators concerned about the quality of execution received by trades in these markets. We know from theoretical models that dealers with extreme risk exposures offer most competitive prices. To the extent that public buy (sell) trades in the spot market are not executed by dealers having relatively long (short) standardized exposure, these trades are not likely to receive the best possible price. Clearly, by enabling a better matching between public trades and dealers with divergent exposure, the quality of execution can be improved in the UK government bond market. The possible ways of achieving a better matching between public investors (liquidity demanders) and dealers with divergent exposure (ideally placed liquidity providers) are the introduction of a central quote posting system or a consolidated limit order book. Such market reforms would reduce search costs, enable better matching between buyers and 
sellers, and thereby improve risk sharing and liquidity provision in these markets.

\section{Concluding Remarks}

In this paper, we employed a comprehensive dataset from the Bank of England containing the close-of-business spot and futures positions of fifteen UK government bond dealers to provide empirical evidence how market intermediaries manage the hedgeable market component of their core business risk and its relationship with market quality in the context of capital constraints. We found that dealers are extensively engaged in selective market risk-taking through a duration targeting policy, and during our sample period, their duration target was consistently negative. The size of their futures position was comparable in magnitude to their spot position and the futures position usually reinforced the risk of their spot position. The dealers actively used futures contracts to partially hedge the changes in their spot position. We found that dealers used futures markets to a greater extent when the cost of hedging was lower (an evidence consistent with Stulz (1984)), when the costs of regulatory distress through breach of capital adequacy requirements were greater, and during periods of greater economic uncertainty.

We also found that higher turnover dealers carried a greater amount of risk on their books and hedged the changes in their spot risk less compared to lower turnover dealers. This behaviour is consistent with the predictions of Stulz (1996). Interestingly, we found that higher turnover dealers did not earn significantly greater profits than lower turnover dealers from their selective risk taking policy. This suggested that the government bond market was reasonably efficient and the informational advantage of higher turnover bond dealers as a result of executing a greater proportion of order flow, was more perceived than real.

As regards to market quality, we found strong and asymmetric price effects when dealers carried substantial market risk exposure on their books. Trades that worsened (relaxed) dealers' capital adequacy constraints experienced significantly worse (better) prices. This finding lends strong support to Froot and Stein's (1998) argument about price effects of capital constraints. We believe that regulators interested in market quality should be concerned about this adverse effect of dealers' 
duration targeting activity.

Finally, on the subject of risk sharing among dealers, we found that dealers with relatively long (short) stadardized total risk exposures sold (bought) a greater amount of standardized total risk exposure the next day. However, this seemed to be driven by their trading in the futures market and not by their trading in the spot market. In the spot market, we did not find that dealers with longer (shorter) standardized total risk exposure sold (bought) greater amount of spot risk. This finding has important implications for the regulators concerned about the quality of execution offered to public investors. In the context of Ho and Stoll (1983) and Biais (1993), to the extent that public buy (sell) trades are not executed by dealers with extreme long (short) exposures (relative to their duration targets), these trades will not receive the best execution possible. This suggests that trading costs in this government bond market can be lowered if investors can be matched more effectively with dealers carrying extreme exposures. This can be achieved by the introduction of market reforms such as having a central quote posting facility or a consolidated limit order book. Such reforms will enable a better matching of liquidity demanders (i.e. investors) and most suitable liquidity providers (dealers with extreme exposures). They would reduce trading costs of investors, and improve risk sharing and liquidity provision in these markets.

Although this paper analysed the UK government bond market, we believe that our findings can be generalised to intermediaries operating in a wide range of other spot markets, in particular, the foreign exchange market, the Treasury bond market and numerous over-the-counter markets. The intermediaries in these markets face conditions and incentives that are not dissimilar to those faced by our bond dealers. These other markets also have a decentralized semi-transparent structure, and the asset traded is also a macro-economic variable with largely public information. Furthermore, there exist liquid futures markets that enable efficient hedgeing of market risk. Finally, the dealers competing of business in these markets also face capital adequacy constraints, which may be either explicitly imposed by regulators or implicitly imposed through the risk budgeting process within dealer firms. Therefore, we believe that our findings are likely to characterise, to a great extent, the 
behaviour of intermediaries in these other markets as well.

\section{References}

Allayannis, G. and E. Ofek, 1997, 'Exchange Rate Exposure, Hedging and the Use of Foreign Currency Derivatives,' Unpublished Working Paper, Darden School of Business, University of Virginia.

Anderson, R. W. and J-P. Danthine, 1980, 'Hedging and Joint Production: Theory and Illustrations,' Journal of Finance, 35, 487-498.

Anderson, R.W. and J-P. Danthine, 1981, 'Cross Hedging,' Journal of Political Economy, 89, 1182-1196.

Barclay, Michael J. and Jerome B. Warner, 1993, 'Stealth trading and volatility: Which trades move prices?,' Journal of Financial Economics, 34, 281-306.

Barnhill, Theodore M., 1990, 'Quality Option Profits, Switching Option Profits and Variation in Margin Costs: Evalation of their Size and Impact on the Treasury Bond Futures Prices,' Journal of Financial and Quantitative Analysis, 25, 1, 65-86.

Biais, B., 1993, 'Price Formation and Equilibrium Liquidity in Fragmented and Centralized Markets,' Journal of Finance, 48, 157-186.

Block, S.B. and T.J. Gallagher, 1986, 'The use of interest rate futures and options by corporate financial managers', Financial Management 15, 73-78.

Booth, J.R., R.L. Smith and R.W. Stolz, 1984, 'The use of interest futures by financial institutions', Journal of Bank Research 15, 15-20.

Breeden D. T. and S. Viswanathan, 1996, 'Why do Firms Hedge? An Asymmetric Information Model,' Unpublished Working Paper, Fuqua School of Business, Duke University.

Chaumeton, L., G. Conner and R. Curds, 1996, 'A Global Stock and Bond Model', Financial Analysts Journal, 65-74.

Cohen K. J., G. A. Hawawini, S. F. Maier, R. A. Schwartz and D. K. Whitcomb, 1983, "Friction in the Trading Process and the Estimation of Systematic Risk," Journal of Financial Economics, 12, no. 2, 263-278.

Degeorge, F., B. Moselle and R. Zeckhauser, 1996, 'Hedging and Gambling: Corporate Risk Choice When Informing the Market,' Unpublished Working Paper, HEC School of Management.

DeMarzo, Peter and Darrell Duffie, 1991, 'Corporate financial hedging with proprietary information', Journal of Economic Theory 53, 261-286.

DeMarzo, Peter and Darrell Duffie, 1995, 'Corporate incentives for hedging and hedge accounting', Review of Financial Studies 8, 743-772.

Dolde, Walter, 1993, 'Use of foreign exchange and interest rate risk management in large firms', Working Paper, University of Connecticut.

Dolde, Walter, 1995, 'Hedging, leverage and primitive risk', Journal of Financial Engineering 3, 187-216.

Easley, David, and Maureen O'Hara, 1987, 'Price, Trade Size and Information in Securities Markets', Journal of Financial Economics, 19, 69-90.

Easley, David, Nicholas M. Kiefer and Maureen O'Hara, 1997, 'One Day in the Life of a Very Common Stock', Review of Financial Studies, 10(3), 805-835.

Francis, Jennifer and Jens Stephan, 1990, 'Characteristics of hedging firms: An empirical examination' in Robert J. Schwartz and Clifford W. Smith, Jr, eds: Advanced Strategies in Financial Risk Management (New York Institute of Finance, Englewood Cliffs, NJ and Simon \& Schuster).

Froot, Kenneth A., David S. Scharfstein and Jeremy C. Stein, 1993, 'Risk management: Coordinating Corporate Investment and Financing Policies', Journal of Finance 48, 1629-1658. 
Froot Kenneth and Jeremy Stein, 1998, 'Risk Management, Capital Budgeting and Capital StructurePolicy for Financial Institutions: an integrated approach', Journal of Financial Economics, 47, 55-82.

Géczy, C., B.A. Minton and C. Schrand, 1997, 'Why Firms Use Currency Derivatives,' Journal of Finance, 52, 1323-1354.

Géczy, C., B.A. Minton and C. Schrand, 1999, 'Choices Among Alternative Risk Management Strategies: Evidence from Natural Gas Industry,' working paper, Wharton Business School.

Graham, John, and David Smith, 1999, 'Tax Incentives to Hedge,' Journal of Finance 54, 2241-2262.

Graham, John, and Daniel A. Rogers, 2000, 'Does Corporate Hedging Increase Firm Value? An Empirical Analysis,' Working Paper, Fuqua School of Business, Duke University.

Guay, W.R., 1998, 'The Impact of Derivatives on Firm Risk: An Empirical Examination of New Derivative Users,' Working Paper, The Wharton School, University of Pennsylvania.

Guay, W.R. and S.P. Kothari, 2001, 'How much do firms hedge with derivatives,' Working Paper, The Wharton School, University of Pennsylvania.

Hansch, Oliver, Narayan Y Naik and S Viswanathan, 1998, 'Do Inventories Matter in Dealership Markets? Evidence from the London Stock Exchange,' Journal of Finance Vol. 53, no 5, 1623-1655.

Hansch, Oliver, Narayan Y. Naik and S. Viswanathan, 1999, 'Preferencing, internalization, best execution and dealer profits', Journal of Finance, Vol. 54, no 5, 1799-1828.

Hansch, Oliver, and Victorial Saporta, 1999, 'Gross Trading Revenues in Gilt-Edged Market Making', Working Paper, Bank of England.

Haushalter, D., 1997, 'The Role of Corporate Hedging: Evidence from Oil and Gas Producers,' Unpublished Working Paper, Purdue University.

Hemler, Michael L., 'The Quality Delivery Option in Treasury Bond Futures Contracts,' Journal of Finance, vol 45, no 5, 101-113.

Hentschel, L. and S.P. Kothari, 'Are Corporations Reducing or Taking Risks with Derivatives?' Unpublished Working Paper, Simon School, University of Rochester.

Hogan, Arthur M.B. and Cifford Rossi 1997, 'The Characteristics of Derivatives Users: An Analysis of the Thrift Industry,' Journal of Economics and Business, 49, 587-598.

Holthausen, D.M., 1979, 'Hedging and the Competitive Firm under Price Uncertainty,' American Economic Review, 69, 989-995.

Ito, Takatoshi, Richard Lyons and Michael Melvin, 1998, 'Is there private information in the FX market? Evidence from the Tokyo experiment', Journal of Finance, 53, 3, 1111-1130.

Kane Alex, and Alan J. Marcus, 1986, Valuation and Optimal Exercise of the Wild Card Option in the Treasury Bond Futures Market,' Journal of Finance, vol 41, no 1, 195-207.

Kiem, D.B. and A Madhavan, 1996, 'The upstairs market for large-block transactions: analysis and measurement of price effects,' Review of Financial Studies, 9, 1-36.

Koski Lynch Jennifer, and Jeffrey Pontiff, 1999, 'How Derivatives are Used? Evidence from the Mutual Fund Industry', Journal of Finance, 54, 2, 791-816.

Lewent, Judy, and A. John Kearney, 1990, 'Identifying measuring and hedging currency risk at Merck', Journal of Applied Corporate Finance 3, 19-28.

Ljungqvist, Lars, 1994, 'Asymmetric information: A rationale for corporate speculation', Journal of Financial Intermediation 3, 188-203.

Lyons, Richard, 1995, 'Tests of microstructural hypothesis in the foreign-exchange market, Journal of Financial Economics, 39, 321-351. 
May, Don O., 1995, 'Do managerial motives influence firm risk reduction strategies?', Journal of Finance 50, 1275-1290.

Mellow A. and J. Parsons, 2000, 'Hedging and Liquidity', Review of Financial Studies, 13, 1, 127-153.

Merrick, John J. Jr., 1988, 'Hedging with Mispriced futures', Journal of Financial and Quantitative Analysis 23(4), 451-464.

Mian, Shehzad L., 1996, 'Evidence on corporate hedging policy', Journal of Financial and Quantitative Analysis 31, 419-439.

Naik Narayan Y and Pradeep K Yadav, 2001, 'Do Correlated Exposures Influence Intermediary Decision Making? Evidence from Trading Behaviour of Equity Dealers.' Working paper London Business School.

Nance, Deana R., Clifford W. Smith, Jr. and Charles W. Smithson, 1993, 'On the determinants of corporate hedging', The Journal of Finance 48, 267-284.

Petersen, M.A. and S.R. Thiagarajan, 1998, 'Risk Measurement and Hedging: With and Without Derivatives,' Unpublished Working Paper, Kellogg School, Northwestern University.

Proudman James, 1995, 'The Microstructure of the UK Gilt Market', Working Paper Series No. 38, Bank of England.

Raposo, C.C., 1996, 'Corporate Risk Management and Optimal Hedging Disclosure,' Working Paper, London Business School.

Schrand, C.M. and H. Unal, 1998, 'Hedging and Coordinated risk management: Evidence from hedging and thrift conversion', Journal of Finance, 53, 3, 979-1014.

Shapiro, Alan C. and Sheridan Titman, 1986, 'An integrated approach to corporate risk management', in Joel Stern and Donald Chew eds: The Revolution in Corporate Finance (Basil Blackwell Ltd, Oxford).

Smith, Clifford W and René Stulz, 1985, 'The determinants of firms' hedging policies', Journal of Financial and Quantitative Analysis 20, 391-405.

Stulz, René, 1984, 'Optimal hedging policies', Journal of Financial and Quantitative Analysis 19, 127140.

Stulz, René, 1996, 'Rethinking risk management', Journal of Applied Corporate Finance 9, 8-24.

Tufano, Peter, 1996, 'Who manages risk? An empirical examination of risk management practices in the gold mining industry', Journal of Finance 51, 1097-1137.

Tufano, Peter and Jonathan Headley, 1994a, 'Banc One Corporation: Asset liability management', Journal of Applied Corporate Finance 7, 33-51.

Tufano, Peter and Jonathan Headley, 1994b, 'Union Carbide Corporation: Interest rate risk management', Harvard Business School, Case Number 294-057.

Tufano, Peter and Jon Serbin, 1993, 'American Barrick Resources Corporation: Managing Gold Price Risk', Harvard Business School, Case Number 293-128.

Wharton School and the Chase Manhattan Bank, NA, February 1995, Survey of Derivative Usage Among US Non-financial Firms, Executive Summary.

Whidbee, David A. and Mark Wohar, 1999, 'Derivative activities and managerial incentives in the banking industry', Journal of Corporate Finance, 5, 251-276. 
Appendix A: Names and Amounts Outstanding of the UK Govt. bonds

\begin{tabular}{|c|c|c|c|}
\hline Short Maturity & Amount $£ \mathrm{~m}$ & Long & Amount $£ \mathrm{~m}$ \\
\hline 9 Treasury 1994 & 1,400 & 8 3/4 Treasury 2017 & 6,950 \\
\hline 12 1/2 Exchequer 1994 & 1,240 & 8 Treasury 2013 & 4,950 \\
\hline 10 1/4 Exchequer 1995 & 2,500 & 9 Treasury 2012 & 5,150 \\
\hline 12 3/4 Treasury 1995 & 840 & 9 Conversion 2011 & 4,273 \\
\hline 12 Treasury 1995 & 2,350 & $61 / 4$ Treasury 2010 & 4,750 \\
\hline 10 Conversion 1996 & 3,409 & 8 Treasury 2009 & 3,100 \\
\hline 15 1/4 Treasury 1996 & 1,150 & Double-dated & \\
\hline 13 1/4 Exchequer 1996 & 800 & 11 3/4 Treasury 2003/2007 & 3,150 \\
\hline 14 Treasury 1996 & 770 & 12 1/2 Treasury 2003/2005 & 2,200 \\
\hline 8 3/4 Treasury 1997 & 5,550 & 8 Treasury 2002/2006 & 2,000 \\
\hline 10 1/2 Exchequer 1997 & 3,700 & 11 1/2 Treasury 2001/2004 & 1,620 \\
\hline 7 Treasury Conv 1997 & 2,000 & 13 1/2 Treasury 2004/2008 & 1,250 \\
\hline 13 1/4 Treasury 1997 & 1,290 & $63 / 4$ Treasury $1995 / 1998$ & 1,200 \\
\hline 15 Exchequer 1997 & 830 & 12 Exchequer 2013/2017 & 1,000 \\
\hline 7 11/4 Treasury 1998 & 7,850 & 5 1/2 Treasury 2008/2012 & 1,000 \\
\hline 12 Exchequer 1998 & 3,909 & 14 Treasury 1998/2001 & 970 \\
\hline 9 3/4 Exchequer 1998 & 3,550 & 7 3/4 Treasury 2012/2015 & 800 \\
\hline 15 1/2 Treasury 1998 & 935 & 3 1/2 Funding 1999/2004 & 543 \\
\hline 6 Treasury 1999 & 5,900 & 12 Exchequer 1999/2002 & 105 \\
\hline Floating Rate 1999 & 2,500 & 13 3/4 Treasury 2000/2003 & 53 \\
\hline 12 1/4 Exchequer 1999 & 3,050 & 15 Exchequer 1990/95 & 214 \\
\hline 9 1⁄2 Treasury 1999 & 1,900 & Undated & \\
\hline 10 1/4 Conversion 1999 & 1,798 & $31 / 2$ War & 1,909 \\
\hline $101 / 2$ Treasury 1999 & 1,252 & $31 / 2$ Conv & 119 \\
\hline Medium & & $21 / 2$ Treasury & 475 \\
\hline 9 Conversion 2000 & 5,358 & 4 Consolidated & 359 \\
\hline 8 Treasury 2000 & 4,800 & $21 / 2$ Consolidated & 275 \\
\hline 13 Treasury 2000 & 3,171 & 3 Treasury & 56 \\
\hline $81 / 2$ Treasury 2000 & 109 & 2 1/2 Annuities & 3 \\
\hline 7 Treasury '2001'A & 2,500 & $23 / 4$ Annuities & 1 \\
\hline 10 Treasury 2001 & 4,406 & Index-Linked & \\
\hline 9 3/4 Conversion 2001 & 35 & 2 1/2 I-L Treasury 2001 & 1,500 \\
\hline $91 / 2$ Conversion 2001 & 3 & 2 1/2 I-L Treasury 2003 & 1,050 \\
\hline 9 3/4 Treasury 2002 & 6,527 & 4 3/8 I-L Treasury 2004 & 1,000 \\
\hline 9 Exchequer 2002 & 83 & 2 I-L Treasury 2006 & 1,550 \\
\hline 10 Conversion 2002 & 21 & 2 1/2 I-L Treasury 2009 & 1,550 \\
\hline 9 1/2 Conversion 2002 & 2 & 2 1/2 I-L Treasury 2011 & 1,950 \\
\hline 8 Treasury 2003 & 7,600 & 2 1/2 I-L Treasury 2013 & 2,300 \\
\hline 10 Treasury 2003 & 2,503 & 2 1/2 I-L Treasury 2016 & 2,550 \\
\hline 9 3/4 Conversion 2003 & 11 & 2 1/2 I-L Treasury 2020 & 2,400 \\
\hline 6 3/4 Treasury 2004 & 6,250 & 2 1/2 I-L Treasury 2024 & 2,000 \\
\hline 9 1/2 Conversion 2004 & 3,412 & 4 1/8 I-L Treasury 2030 & 1,300 \\
\hline 10 Treasury 2004 & 20 & 2 I-L Treasury 1996 & 1,200 \\
\hline $81 / 2$ Treasury 2005 & 8,900 & 4 5/8 I-L Treasury 1998 & 800 \\
\hline 9 1/2 Conversion 2005 & 4,842 & 2 1/2 I-L Treasury Conv 1999 & 2 \\
\hline 7 3/4 Treasury 2006 & 3,900 & & \\
\hline 9 3/4 Conversion 2006 & 6 & & \\
\hline $81 / 2$ Treasury 2007 & 5,497 & & \\
\hline 9 Treasury 2008 & 5,321 & & \\
\hline
\end{tabular}




\section{Appendix B: Salient Financial Details of UK Government Bond Dealer Firms in London}

Trading in UK Government bonds is organised on the London Stock Exchange in a competitive dealership environment. Each dealer firm is required to be an independent legal entity separately capitalised from the parent company. The dealer firms are private companies not listed or quoted or traded on any exchange. This appendix lists salient financial information for dealer firms for which the UK Companies House could provide us the annual reports. The information below corresponds to the latest accounting year-end date falling within the sample period (August 1994 to December 1995) for the particular company. All figures are in millions of Pound Sterling.

\begin{tabular}{|c|c|c|c|c|c|c|}
\hline Name of Dealer Firm & Name of Ultimate Parent & $\begin{array}{l}\text { Paid Up Equity } \\
\text { Share Capital }\end{array}$ & $\begin{array}{c}\text { P \& L } \\
\text { Reserves }\end{array}$ & $\begin{array}{c}\text { Sundry } \\
\text { Reserves }\end{array}$ & $\begin{array}{l}\text { Shareholders } \\
\text { Funds }\end{array}$ & Profit (Loss) \\
\hline Baring Sterling Bonds (Unlimited) & ING, Netherlands & 18.9 & $(11.8)$ & 0.0 & 7.1 & 0.8 \\
\hline Credit Suisse First Boston Gilts Ltd & Credit Suisse Group, Switzerland & 16.7 & $(7.9)$ & 7.5 & 16.3 & 0.1 \\
\hline Deutsche Bank Gilts Ltd & Deutsche Bank AG, Germany & 30.0 & $(4.3)$ & 0.0 & 25.7 & $(5.3)$ \\
\hline $\begin{array}{l}\text { Goldman Sachs Government } \\
\text { Securities (UK) }\end{array}$ & Goldman Sachs Group ,USA. & 2.6 & $(25.8)$ & 67.4 & 44.2 & $(1.1)$ \\
\hline Greenwich Natwest Gilts Ltd & National Westminster Bank plc, UK & 33.0 & $(13.6)$ & 0 & 19.4 & 0.3 \\
\hline HSBC Greenwell (Unlimited) & HSBC Holdings plc & 30.0 & 9.5 & - & 39.5 & 5.9 \\
\hline J P Morgan Sterling Securities Ltd & J P Morgan \& Co, USA & 19.0 & $(10.2)$ & 31.5 & 40.3 & 0.8 \\
\hline Kleinwort Bensen Gilts Ltd & Dresdener Bank (Germany) AG & 5.2 & 11.1 & 0.0 & 16.3 & $(0.8)$ \\
\hline Merrill Lynch Gilts Ltd & Merrill Lynch \& Co Inc, USA & 33.0 & 2.4 & 0.0 & 35.4 & 4.3 \\
\hline Nomura Gilts Limited & The Nomura Securities Co Ltd, Japan & 20.0 & 1.3 & 0.0 & 21.3 & 0.2 \\
\hline Societe Generale Gilts Ltd & Societe Generale (France) & 15.0 & 0.0 & 0.0 & 15.0 & (1.6) \\
\hline UBS Securities Trading Ltd & Union Bank of Switzerland & 24.0 & 10.7 & 0.0 & 34.7 & $(2.3)$ \\
\hline
\end{tabular}

Source: The UK Companies House 
Table I: Salient Features of the Data

The top panel reports the mean, median, minimum, maximum and Overall values of magnitude of total (spot-plus-futures) exposure, spot exposure, futures exposure, the magnitude of futures exposure as a percentage of total exposure, mean offset by futures exposure of spot exposure, mean offset by demeaned futures exposure of demeaned spot exposure and percentage of days when demeaned futures exposure is of the opposite sign of the spot exposure using theoretical (duration-based) risk measure as well as empirical (regression beta-based) risk measure.

\begin{tabular}{|c|c|c|c|c|c|c|c|c|c|c|}
\hline \multirow{2}{*}{$\begin{array}{l}\text { Sample Statistics Across the Fifteen UK } \\
\text { Government Bond Dealers }\end{array}$} & \multicolumn{5}{|c|}{ With Theoretical Risk Measure } & \multicolumn{5}{|c|}{ With Empirical Risk Measure } \\
\hline & Mean & Median & Minim. & Maxim. & Overall & Mean & Median & Minim. & Maxim. & Overall \\
\hline Magnitude of Total Risk Exposure $£$ m & 12 & 10 & 2 & 32 & 161 & 10 & 8 & 1 & 26 & 134 \\
\hline Spot Risk Exposure $£ \mathrm{~m}$ & -6 & -3 & -28 & 11 & -87 & -4 & -3 & -22 & 7 & -61 \\
\hline Futures Risk Exposure $£$ m & -5 & -3 & -20 & 0 & -73 & -5 & -3 & -20 & 0 & -73 \\
\hline Futures Exposure as $\%$ of Total Exposure & 36 & 33 & 16 & 60 & 47 & 42 & 43 & 20 & 63 & 53 \\
\hline Mean offset by Futures of Spot Exp. \% & 27 & 19 & 2 & 67 & 3 & 30 & 27 & 3 & 65 & 5 \\
\hline Mean offset by demeaned $\mathrm{F}$ of demeaned $\mathrm{S} \%$ & 40 & 36 & 16 & 75 & 50 & 44 & 44 & 8 & 72 & 58 \\
\hline Days when demeaned F and S offset $\%$ & 68 & 69 & 44 & 93 & 72 & 71 & 76 & 37 & 91 & 79 \\
\hline
\end{tabular}

The bottom panel reports the mean, median, minimum, maximum and Overall values of average daily profits from risk taking as well as average daily profits per unit of risk taking using the empirical risk measure.

\begin{tabular}{|c|c|c|c|c|c|c|c|c|c|c|}
\hline \multirow{2}{*}{$\begin{array}{l}\text { Sample Statistics Across the Fifteen UK } \\
\text { Government Bond Dealers }\end{array}$} & \multicolumn{5}{|c|}{ Average Daily Profits (in $£ ’ 000$ ) } & \multicolumn{5}{|c|}{ Average Daily Scaled Profits (in basis points) } \\
\hline & Mean & Median & Minim. & Maxim. & Overall & Mean & Median & Minim. & Maxim. & Overall \\
\hline Overnight Profit from Risk Taking Activity & -2.6 & -3.0 & -54 & 40 & 22 & -1.3 & -4.5 & -40 & 25 & 0.3 \\
\hline
\end{tabular}


Table II: Mean Reversion in Dealers' Total Risk Exposure

This table shows the mean reversion coefficients of the following regression for each dealer using the theoretical (based on duration) measure or risk as well as empirical (based on beta vis-à-vis futures contract) measure.

$$
\Delta\left(S_{k, t}+F_{k, t}\right)=\alpha_{k}+\gamma_{k}\left(S_{k, t}+F_{k, t}\right)+\varepsilon_{k, t}
$$

Figures in bold face (italics) indicate mean-reversion coefficients that are statistically significant at five (ten) percent level.

\begin{tabular}{|c|c|c|c|c|c|c|}
\hline \multirow{2}{*}{ Dealer } & \multicolumn{3}{|c|}{ Theoretical Measure of Risk } & \multicolumn{3}{|c|}{ Empirical Measure of Risk } \\
\hline & $\gamma^{K}$ & Adj-Rsq. & Half-life & $\gamma^{K}$ & Adj-Rsq. & Half-life \\
\hline 1 & $\begin{array}{c}\mathbf{- 0 . 2 0} \\
(-6.20)\end{array}$ & 9.76 & 3.1 & $\begin{array}{c}-\mathbf{0 . 2 2} \\
(-6.53)\end{array}$ & 10.71 & 2.9 \\
\hline 2 & $\begin{array}{c}-0.02 \\
(-1.05)\end{array}$ & 0.75 & 33.9 & $\begin{array}{c}-0.02 \\
(-1.20)\end{array}$ & 0.97 & 28.0 \\
\hline 3 & $\begin{array}{c}\mathbf{- 0 . 0 6} \\
(-3.31)\end{array}$ & 2.99 & 11.3 & $\begin{array}{c}\mathbf{- 0 . 1 3} \\
(-4.94)\end{array}$ & 6.43 & 5.1 \\
\hline 4 & $\begin{array}{c}\mathbf{- 0 . 0 9} \\
(-4.08)\end{array}$ & 4.48 & 7.3 & $\begin{array}{c}\mathbf{- 0 . 1 0} \\
(-4.35)\end{array}$ & 5.07 & 6.5 \\
\hline 5 & $\begin{array}{c}-0.03 \\
(-1.85)\end{array}$ & 0.63 & 36.3 & $\begin{array}{c}-\mathbf{- 0 . 0 5} \\
(-2.80)\end{array}$ & 2.15 & 14.4 \\
\hline 6 & $\begin{array}{c}\mathbf{- 0 . 1 0} \\
(-4.26)\end{array}$ & 4.85 & 6.8 & $\begin{array}{c}\mathbf{- 0 . 0 5} \\
(-3.25)\end{array}$ & 2.88 & 13.1 \\
\hline 7 & $\begin{array}{c}\mathbf{- 0 . 0 6} \\
(-3.42)\end{array}$ & 3.19 & 10.1 & $\begin{array}{c}\mathbf{- 0 . 1 5} \\
(-5.43)\end{array}$ & 7.67 & 4.3 \\
\hline 8 & $\begin{array}{c}\mathbf{- 0 . 0 7} \\
(-3.62)\end{array}$ & 3.55 & 17.9 & $\begin{array}{c}\mathbf{- 0 . 0 4} \\
(-2.76)\end{array}$ & 2.10 & 17.3 \\
\hline 9 & $\begin{array}{c}\mathbf{- 0 . 1 5} \\
(-5.31)\end{array}$ & 7.37 & 4.3 & $\begin{array}{c}\mathbf{- 0 . 1 0} \\
(-4.45)\end{array}$ & 5.28 & 6.3 \\
\hline 10 & $\begin{array}{c}\mathbf{- 0 . 0 5} \\
(-2.88)\end{array}$ & 2.29 & 14.9 & $\begin{array}{c}-\mathbf{- 0 . 1 7} \\
(-5.74)\end{array}$ & 8.49 & 3.7 \\
\hline 11 & $\begin{array}{c}\mathbf{- 0 . 0 3} \\
(-2.01)\end{array}$ & 1.12 & 26.1 & $\begin{array}{c}\mathbf{- 0 . 0 5} \\
(-2.84)\end{array}$ & 2.22 & 13.5 \\
\hline 12 & $\begin{array}{c}\mathbf{- 0 . 1 2} \\
(-4.64)\end{array}$ & 5.71 & 5.6 & $\begin{array}{c}\mathbf{- 0 . 1 3} \\
(-4.82) \\
\end{array}$ & 6.15 & 5.2 \\
\hline 13 & $\begin{array}{c}\mathbf{- 0 . 0 6} \\
(-3.38)\end{array}$ & 3.11 & 10.9 & $\begin{array}{c}-\mathbf{0 . 2 0} \\
(-6.22)\end{array}$ & 9.83 & 3.0 \\
\hline 14 & $\begin{array}{c}\mathbf{- 0 . 1 8} \\
(-6.06)\end{array}$ & 9.38 & 3.4 & $\begin{array}{c}\mathbf{- 0 . 3 6} \\
(-8.79)\end{array}$ & 17.88 & 1.6 \\
\hline 15 & $\begin{array}{c}-0.03 \\
(-1.64) \\
\end{array}$ & 1.49 & 25.6 & $\begin{array}{c}-0.03 \\
(-1.76) \\
\end{array}$ & 1.71 & 22.6 \\
\hline
\end{tabular}


Table III: Changes in the Futures Exposure and Changes in the Spot Exposure

This table shows the coefficients of the following regression for each of the fifteen bond dealers using theoretical and empirical measures or risk exposures:

$$
\Delta F_{k, t}=\alpha_{k}+h_{k} \Delta S_{k, t}+h_{k, l} \Delta S_{k, t-1}+\varepsilon_{k, t}
$$

where $k$ indicates the dealer $(k=1,2 \ldots .15), \Delta F_{k, t}$ is the change in Futures Exposure of dealer $k$ from end of day $t-1$ to end of day $t, \Delta S_{k, t}$ is the change in Spot Exposure of dealer $k$ from end of day $t-1$ to end of day $t, \Delta S_{k, t-1}$ is lagged changed in Spot Exposure of dealer $k, h_{k}$ and $h_{k, l}$ are contemporaneous and lagged hedge ratios, and $\alpha_{k}$ and $\varepsilon_{k, t}$ are the intercept and error terms respectively. The table reports results t-statistics of the hedge ratios are reported in parentheses. Figures in bold face indicate significance at 5\% level. Hedge ratios indistinguishable from -1.0 at 5\% level are denoted with an asterisk.

\begin{tabular}{|c|c|c|c|c|c|c|}
\hline \multirow{2}{*}{$\begin{array}{c}\text { Dealer } \\
\qquad\end{array}$} & \multicolumn{3}{|c|}{ With Theoretical Measure of Risk Exposure } & \multicolumn{3}{|c|}{ With Empirical Measure of Risk Exposure } \\
\hline & $\begin{array}{c}\text { Hedge Ratio } \\
\qquad h_{k}\end{array}$ & $\begin{array}{l}\text { Lagged Hedge } \\
\text { Ratio, } h_{k, l}\end{array}$ & $\begin{array}{l}\text { Adjusted } \\
\text { R-square }\end{array}$ & $\begin{array}{c}\text { Hedge Ratio } \\
\qquad h_{k}\end{array}$ & $\begin{array}{l}\text { Lagged Hedge } \\
\text { Ratio, } h_{k, l}\end{array}$ & $\begin{array}{l}\text { Adjusted } \\
\text { R-square }\end{array}$ \\
\hline 1 & $\begin{array}{c}\mathbf{- 0 . 3 7} \\
(-8.69)\end{array}$ & $\begin{array}{c}\mathbf{- 0 . 0 9} \\
(-2.13)\end{array}$ & $22.9 \%$ & $\begin{array}{c}\mathbf{- 0 . 4 7} \\
(-8.80)\end{array}$ & $\begin{array}{c}\mathbf{- 0 . 1 2} \\
(-2.39)\end{array}$ & $23.1 \%$ \\
\hline 2 & $\begin{array}{c}\mathbf{- 0 . 4 2} \\
(-8.13)\end{array}$ & $\begin{array}{c}\mathbf{- 0 . 1 0} \\
(-1.97)\end{array}$ & $20.5 \%$ & $\begin{array}{c}\mathbf{- 0 . 3 6} \\
(-6.00)\end{array}$ & $\begin{array}{c}\mathbf{- 0 . 1 6} \\
(-2.02)\end{array}$ & $13.0 \%$ \\
\hline 3 & $\begin{array}{c}\mathbf{- 0 . 3 9} \\
(-11.93) \\
\end{array}$ & $\begin{array}{c}0.06 \\
(1.63)\end{array}$ & $34.2 \%$ & $\begin{array}{c}\mathbf{- 0 . 5 1} \\
(-11.57) \\
\end{array}$ & $\begin{array}{c}0.03 \\
(0.74)\end{array}$ & $33.0 \%$ \\
\hline 4 & $\begin{array}{c}\mathbf{- 0 . 4 2} \\
(-7.70) \\
\end{array}$ & $\begin{array}{c}-0.02 \\
(-0.53)\end{array}$ & $22.7 \%$ & $\begin{array}{c}\mathbf{- 0 . 5 2} \\
(-7.94) \\
\end{array}$ & $\begin{array}{c}0.01 \\
(0.23)\end{array}$ & $23.7 \%$ \\
\hline 5 & $\begin{array}{c}\mathbf{- 0 . 7 6} \\
(-20.88) \\
\end{array}$ & $\begin{array}{c}-0.02 \\
(-0.78) \\
\end{array}$ & $62.1 \%$ & $\begin{array}{c}\mathbf{- 0 . 9 9 *} \\
(-23.17) \\
\end{array}$ & $\begin{array}{c}-0.03 \\
(-0.67) \\
\end{array}$ & $64.9 \%$ \\
\hline 6 & $\begin{array}{c}\mathbf{- 0 . 2 7} \\
(-6.02) \\
\end{array}$ & $\begin{array}{c}\mathbf{- 0 . 0 8} \\
(-2.00) \\
\end{array}$ & $11.8 \%$ & $\begin{array}{c}\mathbf{- 0 . 3 3} \\
(-5.95) \\
\end{array}$ & $\begin{array}{c}\mathbf{- 0 . 1 1} \\
(-1.98) \\
\end{array}$ & $11.7 \%$ \\
\hline 7 & $\begin{array}{c}\mathbf{- 0 . 2 0} \\
(-3.50)\end{array}$ & $\begin{array}{c}0.03 \\
(0.50)\end{array}$ & $4.3 \%$ & $\begin{array}{c}\mathbf{- 0 . 2 3} \\
(-3.07)\end{array}$ & $\begin{array}{c}0.05 \\
(0.65)\end{array}$ & $3.1 \%$ \\
\hline 8 & $\begin{array}{c}\mathbf{- 0 . 6 6} \\
(-14.50) \\
\end{array}$ & $\begin{array}{c}\mathbf{- 0 . 0 9} \\
(-2.09)\end{array}$ & $43 \%$ & $\begin{array}{c}\mathbf{- 0 . 8 5} \\
(-15.83) \\
\end{array}$ & $\begin{array}{c}-0.06 \\
(-0.97)\end{array}$ & $47 \%$ \\
\hline 9 & $\begin{array}{c}\mathbf{- 0 . 4 7} \\
(-8.02)\end{array}$ & $\begin{array}{c}-0.10 \\
(-1.76)\end{array}$ & $18.4 \%$ & $\begin{array}{c}\mathbf{- 0 . 6 3} \\
(-7.60)\end{array}$ & $\begin{array}{c}\mathbf{- 0 . 1 7} \\
(-2.23) \\
\end{array}$ & $17.5 \%$ \\
\hline 10 & $\begin{array}{c}\mathbf{- 0 . 5 9} \\
(-12.15) \\
\end{array}$ & $\begin{array}{c}0.01 \\
(0.28)\end{array}$ & $35 \%$ & $\begin{array}{c}\mathbf{- 0 . 6 8} \\
(-11.74)\end{array}$ & $\begin{array}{c}-0.03 \\
(-0.55)\end{array}$ & $35.2 \%$ \\
\hline 11 & $\begin{array}{c}\mathbf{- 0 . 6 7} \\
(-17.14)\end{array}$ & $\begin{array}{c}\mathbf{- 0 . 0 7} \\
(-1.97)\end{array}$ & $49.9 \%$ & $\begin{array}{c}\mathbf{- 1 . 0 0 *} \\
(-20.47)\end{array}$ & $\begin{array}{c}-0.04 \\
(-0.82)\end{array}$ & $59.6 \%$ \\
\hline 12 & $\begin{array}{l}\mathbf{- 0 . 8 0 *} \\
(-6.63) \\
\end{array}$ & $\begin{array}{c}0.01 \\
(0.06) \\
\end{array}$ & $50.7 \%$ & $\begin{array}{l}\mathbf{- 0 . 9 4 *} \\
(-5.76) \\
\end{array}$ & $\begin{array}{c}0.01 \\
(0.05) \\
\end{array}$ & $45.1 \%$ \\
\hline 13 & $\begin{array}{c}\mathbf{- 0 . 4 4} \\
(-9.21) \\
\end{array}$ & $\begin{array}{c}0.11 \\
(1.43) \\
\end{array}$ & $25.3 \%$ & $\begin{array}{c}\mathbf{- 0 . 4 3} \\
(-7.68) \\
\end{array}$ & $\begin{array}{c}0.05 \\
(0.86) \\
\end{array}$ & $19.3 \%$ \\
\hline 14 & $\begin{array}{c}\mathbf{- 0 . 5 5} \\
(-15.13)\end{array}$ & $\begin{array}{c}\mathbf{- 0 . 1 3} \\
(-3.58)\end{array}$ & $50.5 \%$ & $\begin{array}{c}\mathbf{- 1 . 0 6 *} \\
(-25.84)\end{array}$ & $\begin{array}{c}\mathbf{- 0 . 1 2} \\
(-3.15)\end{array}$ & $73.8 \%$ \\
\hline 15 & $\begin{array}{c}\mathbf{- 0 . 6 8} \\
(-10.97)\end{array}$ & $\begin{array}{c}\mathbf{- 0 . 1 3} \\
(-2.27)\end{array}$ & $44 \%$ & $\begin{array}{c}\mathbf{- 0 . 6 7} \\
(-7.69)\end{array}$ & $\begin{array}{c}-0.26 \\
(-1.05)\end{array}$ & $12.6 \%$ \\
\hline
\end{tabular}




\section{Table IV: Hedge Ratios in different Market Conditions}

This table examines the determinants of the time-series variation in the hedge ratios and reports the results from the following regression:

$$
\begin{aligned}
\Delta F_{k, t}= & \gamma_{0}+\Sigma D_{k, t}\left(h_{k} \Delta S_{k, t}+h_{k, l} \Delta S_{k, t-1}\right) \\
& +\left(\gamma_{1} \operatorname{Vol}_{t}+\gamma_{2} S_{k, t-1}^{S t d}+\gamma_{3} \Delta S_{k, t-1}^{S t d}+\gamma_{4} D_{t}^{M i s p}+\gamma_{5} D_{t}^{A n n}+\gamma_{6} D_{t}^{d b A n n}\right) \Delta S_{k, t}+\omega_{k, t}
\end{aligned}
$$

where $k$ indicates the dealer $(k=1,2 \ldots .15), \Delta F_{k, t}$ is the change in Futures Exposure of dealer $k$ from end of day $t-1$ to end of day $t, \Delta S_{k, t}$ is the change in Spot Exposure of dealer $k$ from end of day $t-1$ to end of day $t, \Delta S_{k, t-1}$ is lagged changed in Spot Exposure of dealer $k, h_{k}$ and $h_{k, l}$ are contemporaneous and lagged hedge ratios, $D_{k, t}$ is a dummy variable which takes the value 1 for observations corresponding to dealer $k, V_{o l} l_{t}$ is the standardized absolute value of the open-to-close price change of the near maturity long gilt futures contract, $S_{k, t-1}^{S t d}\left(\Delta S_{k, t-1}^{S t d}\right)$ is the standardized level (change in level) of dealer $k$ 's spot exposure as the end of day $t-1, D_{t}^{\text {Misp }}$ is a dummy variable which takes the value 1 when hedging requires buying (selling) underpriced (overpriced) futures and the value -1 when hedging requires selling (buying) underpriced (overpriced) futures, $D_{t}^{A n n}\left(D_{t}^{d b A n n}\right.$ ) is a dummy variable indicating if day $t$ was an announcement day (a day before an announcement day), $\gamma_{0}$ and $\omega_{k, t}$ are the intercept and error terms respectively. 


\begin{tabular}{|c|c|c|c|c|c|c|}
\hline \multirow{2}{*}{$\begin{array}{c}\text { Dealer } \\
\text { K }\end{array}$} & \multicolumn{3}{|c|}{ Theoretical Measure of Risk Exposure } & \multicolumn{3}{|c|}{ Empirical Measure of Risk Exposure } \\
\hline & $h_{k}$ & $h_{k, l}$ & $\begin{array}{c}\text { Slope } \\
\text { Coefficients } \\
\text { on }\end{array}$ & $h_{k}$ & $h_{k, l}$ & $\begin{array}{c}\text { Slope } \\
\text { Coefficients } \\
\text { on }\end{array}$ \\
\hline 1 & $\begin{array}{c}\mathbf{- 0 . 3 3} \\
(-5.59)\end{array}$ & $\begin{array}{l}\mathbf{- 0 . 0 9} \\
(-2.03)\end{array}$ & & $\begin{array}{c}\mathbf{- 0 . 3 9} \\
(-5.26)\end{array}$ & $\begin{array}{c}\mathbf{- 0 . 1 2} \\
(-2.17)\end{array}$ & \\
\hline 2 & $\begin{array}{c}\mathbf{- 0 . 4 3} \\
(-8.37) \\
\end{array}$ & $\begin{array}{c}\mathbf{- 0 . 1 1} \\
(-2.61)\end{array}$ & & $\begin{array}{l}\mathbf{- 0 . 3 8} \\
(-6.33)\end{array}$ & $\begin{array}{c}-\mathbf{- 0 . 1 8} \\
(-3.11)\end{array}$ & \\
\hline 3 & $\begin{array}{c}\mathbf{- 0 . 4 0} \\
(-6.87) \\
\end{array}$ & $\begin{array}{c}0.06 \\
(1.32)\end{array}$ & & $\begin{array}{l}\mathbf{- 0 . 4 9} \\
(-6.31)\end{array}$ & $\begin{array}{c}0.02 \\
(0.24)\end{array}$ & \\
\hline 4 & $\begin{array}{c}\mathbf{- 0 . 4 1} \\
(-5.14) \\
\end{array}$ & $\begin{array}{c}-0.06 \\
(-0.80)\end{array}$ & & $\begin{array}{c}\mathbf{- 0 . 4 7} \\
(-4.66) \\
\end{array}$ & $\begin{array}{c}-0.03 \\
(-0.35)\end{array}$ & \\
\hline 5 & $\begin{array}{c}\mathbf{- 0 . 8 0} \\
(-13.54)\end{array}$ & $\begin{array}{c}-0.01 \\
(-0.38)\end{array}$ & & $\begin{array}{c}\mathbf{- 1 . 0 3 *} \\
(-14.26)\end{array}$ & $\begin{array}{c}-0.02 \\
(-0.35)\end{array}$ & \\
\hline 6 & $\begin{array}{c}\mathbf{- 0 . 2 6} \\
(-3.68)\end{array}$ & $\begin{array}{l}-0.09 \\
(-1.51)\end{array}$ & & $\begin{array}{c}-\mathbf{- 0 . 3 2} \\
(-3.35)\end{array}$ & $\begin{array}{c}-0.09 \\
(-1.07)\end{array}$ & \\
\hline 7 & $\begin{array}{c}\mathbf{- 0 . 3 8} \\
(-8.46)\end{array}$ & $\begin{array}{c}0.04 \\
(1.44)\end{array}$ & & $\begin{array}{l}\mathbf{- 0 . 4 0} \\
(-7.16)\end{array}$ & $\begin{array}{c}0.07 \\
(1.58)\end{array}$ & \\
\hline 8 & $\begin{array}{c}\mathbf{- 0 . 6 6} \\
(-15.39)\end{array}$ & $\begin{array}{c}\mathbf{- 0 . 0 8} \\
(-3.10)\end{array}$ & & $\begin{array}{c}\mathbf{- 0 . 8 2} \\
(-15.18)\end{array}$ & $\begin{array}{c}-0.04 \\
(-1.40)\end{array}$ & \\
\hline 9 & $\begin{array}{c}\mathbf{- 0 . 5 1} \\
(-6.96)\end{array}$ & $\begin{array}{l}-0.06 \\
(-1.01)\end{array}$ & & $\begin{array}{l}-\mathbf{0 . 6 7} \\
(-6.28)\end{array}$ & $\begin{array}{l}-0.12 \\
(-1.35)\end{array}$ & \\
\hline 10 & $\begin{array}{c}\mathbf{- 0 . 6 3} \\
(-4.75)\end{array}$ & $\begin{array}{c}-0.00 \\
(-0.00)\end{array}$ & & $\begin{array}{l}-\mathbf{- 0 . 7 2} * \\
(-4.33)\end{array}$ & $\begin{array}{c}-0.05 \\
(-0.27)\end{array}$ & \\
\hline 11 & $\begin{array}{c}-\mathbf{- 0 . 6 9} \\
(-3.17)\end{array}$ & $\begin{array}{c}-0.07 \\
(-0.34)\end{array}$ & & $\begin{array}{l}-\mathbf{- 1 . 0 3 *} \\
(-3.22)\end{array}$ & $\begin{array}{c}-0.02 \\
(-0.06)\end{array}$ & \\
\hline 12 & $\begin{array}{l}-0.91 \\
(-1.21)\end{array}$ & $\begin{array}{c}0.01 \\
(0.01)\end{array}$ & & $\begin{array}{l}-1.15 \\
(-1.19)\end{array}$ & $\begin{array}{c}-0.01 \\
(-0.01)\end{array}$ & \\
\hline 13 & $\begin{array}{c}-\mathbf{- 0 . 4 6} \\
(-3.13)\end{array}$ & $\begin{array}{c}0.10 \\
(0.73)\end{array}$ & & $\begin{array}{l}\mathbf{- 0 . 3 9} \\
(-2.35)\end{array}$ & $\begin{array}{c}0.02 \\
(0.10)\end{array}$ & \\
\hline 14 & $\begin{array}{c}\mathbf{- 0 . 5 4} \\
(-3.44)\end{array}$ & $\begin{array}{c}-0.11 \\
(-0.68)\end{array}$ & & $\begin{array}{l}-\mathbf{- 0 . 9 7 *} \\
(-3.74)\end{array}$ & $\begin{array}{l}-0.11 \\
(-0.44)\end{array}$ & \\
\hline 15 & $\begin{array}{c}\mathbf{- 0 . 7 2} \\
(-4.26)\end{array}$ & $\begin{array}{c}-0.13 \\
(-0.88)\end{array}$ & & $\begin{array}{l}\mathbf{- 0 . 6 3} \\
(-2.92)\end{array}$ & $\begin{array}{c}-0.24 \\
(-1.22)\end{array}$ & \\
\hline Volatility & & & $\begin{array}{c}\mathbf{- 0 . 0 3} \\
(-2.01)\end{array}$ & & & $\begin{array}{c}-0.03 \\
(-0.64)\end{array}$ \\
\hline Lagged Exposure & & & $\begin{array}{c}\mathbf{- 0 . 0 8} \\
(-5.89) \\
\end{array}$ & & & $\begin{array}{l}\mathbf{- 0 . 1 0} \\
(-6.26)\end{array}$ \\
\hline Mispricing & & & $\begin{array}{c}-\mathbf{- 0 . 0 7} \\
(-5.82)\end{array}$ & & & $\begin{array}{c}\mathbf{- 0 . 0 6} \\
(-3.53)\end{array}$ \\
\hline Lagged Delta S & & & $\begin{array}{c}\mathbf{- 0 . 1 0} \\
(-3.88) \\
\end{array}$ & & & $\begin{array}{c}\mathbf{- 0 . 1 4} \\
(-4.25) \\
\end{array}$ \\
\hline $\begin{array}{l}\text { Announcement } \\
\text { Day dummy }\end{array}$ & & & $\begin{array}{c}\mathbf{0 . 1 1} \\
(2.84)\end{array}$ & & & $\begin{array}{c}\mathbf{0 . 2 2} \\
(4.58)\end{array}$ \\
\hline $\begin{array}{l}\text { Day before } \\
\text { announc. Dummy }\end{array}$ & & & $\begin{array}{c}\mathbf{- 0 . 1 4} \\
(-3.19) \\
\end{array}$ & & & $\begin{array}{c}\mathbf{- 0 . 1 4} \\
(-2.84) \\
\end{array}$ \\
\hline Adj. R-sq. & & & $32.2 \%$ & & & $30.7 \%$ \\
\hline
\end{tabular}


Table V: Relationship between Risk Taking, Hedging and Profits and Dealer Turnover

This table reports the findings when the Duration Ranks, Hedge Ratio Ranks and Profitability Ranks of dealers are regressed on their Turnover Ranks according to the following cross-sectional regressions $(k=1,2, \ldots, 15)$.

$$
\begin{aligned}
\text { Duration Rank } & =c_{0}+c_{1} \text { Turnover } \text { Rank }_{k}+f_{k} \\
\text { Hedge Ratio Rank } & =d_{0}+d_{1} \text { Turnover Rank } k_{k}+g_{k} \\
\text { Profit Rank } k_{k} & =e_{0}+e_{1} \text { Turnover Rank } k_{k}+n_{k}
\end{aligned}
$$

The t-statistic is in the parentheses. Figures in bold face indicate significance at the five percent level.

Panel A: Duration Rank Regression:

\begin{tabular}{|l|c|c|c|}
\hline Risk Measure used & Intercept & Slope Coefficient & Adjusted R-square \\
\hline Theoretical & $\begin{array}{c}2.80 \\
(1.46)\end{array}$ & $\begin{array}{c}\mathbf{0 . 6 5} \\
(3.08)\end{array}$ & $37.8 \%$ \\
\hline Empirical & $\begin{array}{c}2.14 \\
(1.25)\end{array}$ & $\begin{array}{c}\mathbf{0 . 7 3} \\
(3.87)\end{array}$ & $50.0 \%$ \\
\hline
\end{tabular}

Panel B: Hedge Ratio Rank Regression:

\begin{tabular}{|l|c|c|c|}
\hline Risk Measure used & Intercept & Slope Coefficient & Adjusted R-square \\
\hline Theoretical & $\begin{array}{c}3.15 \\
(1.58)\end{array}$ & $\begin{array}{c}\mathbf{0 . 6 0} \\
(2.75)\end{array}$ & $31.8 \%$ \\
\hline Empirical & $\begin{array}{c}3.31 \\
(1.62)\end{array}$ & $\begin{array}{c}\mathbf{0 . 5 9} \\
(2.61)\end{array}$ & $29.3 \%$ \\
\hline
\end{tabular}

Panel C: Profit Rank Regression:

\begin{tabular}{|l|c|c|c|}
\hline Profit Measure used & Intercept & Slope Coefficient & Adjusted R-square \\
\hline Average Daily Profit & $\begin{array}{c}\mathbf{1 0 . 4 3} \\
(4.34)\end{array}$ & $\begin{array}{c}-0.30 \\
(-1.15)\end{array}$ & $2.2 \%$ \\
\hline Average Daily Scaled Profit & $\begin{array}{c}\mathbf{1 0 . 2 6} \\
(4.24)\end{array}$ & $\begin{array}{c}-0.28 \\
(-1.06)\end{array}$ & $0.9 \%$ \\
\hline
\end{tabular}




\section{Table VI: Price Effects of Capital Constraints}

This table lists the three economic effects that may be important in the ask or bid price price charged to a dealer sell or dealer buy trade. It highlights whether the economic effect is likely to have significant price effect and if so, in which direction theory predicts it will move the bid and ask prices.

\begin{tabular}{|c|c|c|}
\hline & Dealer Buys & Dealer Sells \\
\hline $\begin{array}{c}\text { Exposure } \\
\text { In Top } \\
\text { Decile }\end{array}$ & $\begin{array}{l}* \text { Capital adequacy unimportant } \\
* \text { Away from the mean } \\
\quad \text { => offer worse prices (lower bid price) } \\
\text { * Price impact - negative (lower bid price) }\end{array}$ & $\begin{array}{l}\text { * Capital adequacy unimportant } \\
\text { * Towards the mean } \\
\quad \Rightarrow \text { offer price improvement (lower ask price) } \\
\text { * Price impact effects - nil }\end{array}$ \\
\hline $\begin{array}{c}\text { Exposure } \\
\text { In } \\
\text { Bottom } \\
\text { Decile }\end{array}$ & $\begin{array}{l}\text { * Capital adequacy considerations very } \\
\text { important, buy trade relaxes capital adequacy } \\
\text { constraints => bid higher price, } \\
\text { * Towards the mean } \\
\text { => offer price improvement (higher bid) } \\
\text { * Price impact - negative (lower bid price) }\end{array}$ & $\begin{array}{l}\text { * Capital adequacy considerations very } \\
\text { important, sell trade worsens capital adequacy } \\
\text { constraints => ask higher price } \\
\text { * Away from the mean } \\
\quad \text { => charge worse prices (ask for higher price) } \\
\text { * Price impact effects - nil }\end{array}$ \\
\hline
\end{tabular}




\section{Table VII: Price Effects of Capital Constraints}

This table reports the findings from the following regression when the Overall total exposure belong to the top and bottom decile days, top and bottom quartile days and above median and below median days.

$$
\Delta P_{i, t}=\Sigma D_{i, t} D_{t}+\lambda_{\text {Buy }} D_{\text {Buy }} D_{i, t} \Delta I_{i, t}+\lambda_{\text {Sell }} D_{\text {Sell }} D_{i, t} \Delta I_{i, t}+\xi_{i, t}
$$

where $\Delta P_{i, t}$ is the percentage change in the price of bond $i$ on day $t, D_{i, t}$ is duration of bond $i$ on day $t, D_{t}$ is a dummy representing the day of the sample period, $D_{B u y}$ and $D_{\text {Sell }}$ are dummies that take value of one if the dealers have collectively bought or sold bond $i$ on day $t, \Delta I_{i, t}$ is the change in inventory of all dealers on day $t$, and $\lambda_{B u y}$ and $\lambda_{\text {Sell }}$ are the regression coefficients on change in inventory of the dealers. The t-statistics are reported in parentheses. Figures in bold face (italics) indicate significance at the five (ten) percent level.

Panel A: Extreme Decile-based Analysis

\begin{tabular}{|l|c|c|c|}
\hline Days selected & $\lambda_{\text {Buy }}$ & $\lambda_{\text {Sell }}$ & Adj.-Rsquare \\
\hline Top Decile days & $\begin{array}{c}\mathbf{- 2 . 5 4} \\
(-3.71)\end{array}$ & $\begin{array}{c}-0.70 \\
(-1.01)\end{array}$ & $60.4 \%$ \\
\hline Bottom Decile days & $\begin{array}{c}\mathbf{2 . 1 5} \\
(2.00)\end{array}$ & $\begin{array}{c}-1.88 \\
(-1.78)\end{array}$ & $82.1 \%$ \\
\hline
\end{tabular}

Panel B: Extreme Quartile-based Analysis

\begin{tabular}{|l|c|c|c|}
\hline Days selected & $\lambda_{\text {Buy }}$ & $\lambda_{\text {Sell }}$ & Adj.-Rsquare \\
\hline Top Quartile days & $\begin{array}{c}-0.98 \\
(-1.81)\end{array}$ & $\begin{array}{c}-0.54 \\
(-0.99)\end{array}$ & $66.3 \%$ \\
\hline Bottom Quartile days & $\begin{array}{c}1.30 \\
(1.65)\end{array}$ & $\begin{array}{c}-1.15 \\
(-1.49)\end{array}$ & $81.6 \%$ \\
\hline
\end{tabular}

Panel C: Above Median versus Below Median Analysis

\begin{tabular}{|l|c|c|c|}
\hline Days selected & $\lambda_{\text {Buy }}$ & $\lambda_{\text {Sell }}$ & Adj.-Rsquare \\
\hline Above Median days & $\begin{array}{c}-0.72 \\
(-1.06)\end{array}$ & $\begin{array}{c}-0.30 \\
(-0.45)\end{array}$ & $61.9 \%$ \\
\hline Below Median days & $\begin{array}{c}0.31 \\
(0.46)\end{array}$ & $\begin{array}{c}-0.90 \\
(-1.33)\end{array}$ & $78.3 \%$ \\
\hline
\end{tabular}


Table VIII: Relationship between dealers' total risk exposure level at the end of a day and the change in exposure on the next day

This table reports the relationship between a dealer's end-of-day total-exposure-level rank and her average change-in-exposure rank on the next day. The average change-in-exposure rank is reported as deviation from the median rank of eight and the t-statistic is in the parentheses. Figures in bold face indicate the average change-inexposure ranks that are significantly different from the median rank at the five percent level.

\begin{tabular}{|c|c|c|c|}
\hline $\begin{array}{l}\text { A dealer's total- } \\
\text { exposure-level rank at } \\
\text { the end of a given day }\end{array}$ & $\begin{array}{l}\text { Corresponding } \\
\text { change-in- total-exposure } \\
\text { rank on the next day }\end{array}$ & $\begin{array}{l}\text { Corresponding change-in- } \\
\text { futures-exposure rank on } \\
\text { the next day }\end{array}$ & $\begin{array}{l}\text { Corresponding change- } \\
\text { in-spot- exposure rank on } \\
\text { the next day }\end{array}$ \\
\hline 1 & $\begin{array}{c}1.49 \\
(6.06)\end{array}$ & $\begin{array}{c}\mathbf{0 . 6 1} \\
(2.51)\end{array}$ & $\begin{array}{c}-0.26 \\
(-1.15)\end{array}$ \\
\hline 2 & $\begin{array}{c}\mathbf{0 . 9 5} \\
(3.97)\end{array}$ & $\begin{array}{c}\mathbf{0 . 4 7} \\
(2.00)\end{array}$ & $\begin{array}{c}-0.05 \\
(-0.25)\end{array}$ \\
\hline 3 & $\begin{array}{c}\mathbf{0 . 9 7} \\
(4.30) \\
\end{array}$ & $\begin{array}{c}\mathbf{0 . 4 6} \\
(1.97) \\
\end{array}$ & $\begin{array}{c}0.18 \\
(0.76)\end{array}$ \\
\hline 4 & $\begin{array}{c}\mathbf{0 . 4 5} \\
(1.99)\end{array}$ & $\begin{array}{c}\mathbf{0 . 4 6} \\
(2.02)\end{array}$ & $\begin{array}{c}\mathbf{0 . 4 8} \\
(2.15)\end{array}$ \\
\hline 5 & $\begin{array}{c}\mathbf{0 . 5 2} \\
(2.29)\end{array}$ & $\begin{array}{c}0.33 \\
(1.37)\end{array}$ & $\begin{array}{c}-0.06 \\
(-0.26)\end{array}$ \\
\hline 6 & $\begin{array}{c}0.09 \\
(0.39)\end{array}$ & $\begin{array}{c}0.20 \\
(0.92)\end{array}$ & $\begin{array}{c}-0.37 \\
(-1.57)\end{array}$ \\
\hline 7 & $\begin{array}{c}-0.02 \\
(-0.08) \\
\end{array}$ & $\begin{array}{c}0.15 \\
(0.66) \\
\end{array}$ & $\begin{array}{c}0.22 \\
(0.94) \\
\end{array}$ \\
\hline 8 & $\begin{array}{c}0.38 \\
(1.42) \\
\end{array}$ & $\begin{array}{c}0.22 \\
(1.06) \\
\end{array}$ & $\begin{array}{l}\mathbf{0 . 8 0} \\
3.39 \\
\end{array}$ \\
\hline 9 & $\begin{array}{c}-0.04 \\
(-0.17)\end{array}$ & $\begin{array}{c}-0.09 \\
(-0.39)\end{array}$ & $\begin{array}{c}0.01 \\
(0.04)\end{array}$ \\
\hline 10 & $\begin{array}{c}-0.16 \\
(-0.72) \\
\end{array}$ & $\begin{array}{c}-0.20 \\
(-0.89) \\
\end{array}$ & $\begin{array}{c}0.03 \\
(0.12) \\
\end{array}$ \\
\hline 11 & $\begin{array}{c}\mathbf{- 0 . 4 7} \\
(-2.27)\end{array}$ & $\begin{array}{c}-0.32 \\
(-1.55)\end{array}$ & $\begin{array}{c}0.26 \\
(1.09)\end{array}$ \\
\hline 12 & $\begin{array}{c}\mathbf{- 0 . 6 9} \\
(-3.16)\end{array}$ & $\begin{array}{c}-0.18 \\
(-0.82)\end{array}$ & $\begin{array}{c}-0.14 \\
(-0.63)\end{array}$ \\
\hline 13 & $\begin{array}{c}\mathbf{- 0 . 8 2} \\
(-3.68) \\
\end{array}$ & $\begin{array}{c}-0.25 \\
(1.16) \\
\end{array}$ & $\begin{array}{c}\mathbf{- 0 . 6 6} \\
(-2.98) \\
\end{array}$ \\
\hline 14 & $\begin{array}{c}\mathbf{- 1 . 0 3} \\
(-4.48) \\
\end{array}$ & $\begin{array}{c}\mathbf{- 0 . 7 9} \\
(-3.32) \\
\end{array}$ & $\begin{array}{c}\mathbf{- 0 . 6 0} \\
(-2.87) \\
\end{array}$ \\
\hline 15 & $\begin{array}{c}\mathbf{- 1 . 6 3} \\
(-7.04)\end{array}$ & $\begin{array}{c}\mathbf{- 1 . 0 7} \\
(-4.54)\end{array}$ & $\begin{array}{c}0.17 \\
(0.73)\end{array}$ \\
\hline
\end{tabular}

The table below reports the results of the following cross-sectional regression $(l=1,2, \ldots, 15)$ :

$$
(\text { Average_Change_in_Exposure Rank })_{l}=m_{0}+m_{1}(\text { Exposure_level Rank })_{l}+m_{l}
$$

\begin{tabular}{|c|c|c|c|}
\hline $\begin{array}{l}\text { Dependent variable: } \\
\text { Average change-in }\end{array}$ & Intercept & Slope Coefficient & Adjusted R-square \\
\hline Total-exposure-rank over next day & $\begin{array}{c}\mathbf{1 . 4 5} \\
(12.29)\end{array}$ & $\begin{array}{c}\mathbf{- 0 . 1 8} \\
(12.29)\end{array}$ & $93 \%$ \\
\hline Futures-exposure-rank over next day & $\begin{array}{c}\mathbf{0 . 8 1} \\
(8.97) \\
\end{array}$ & $\begin{array}{c}\mathbf{- 0 . 1 0} \\
(10.19) \\
\end{array}$ & $88 \%$ \\
\hline Spot-exposure rank over next day & $\begin{array}{c}0.16 \\
(0.74)\end{array}$ & $\begin{array}{l}-0.02 \\
(-0.84)\end{array}$ & $-2 \%$ \\
\hline
\end{tabular}



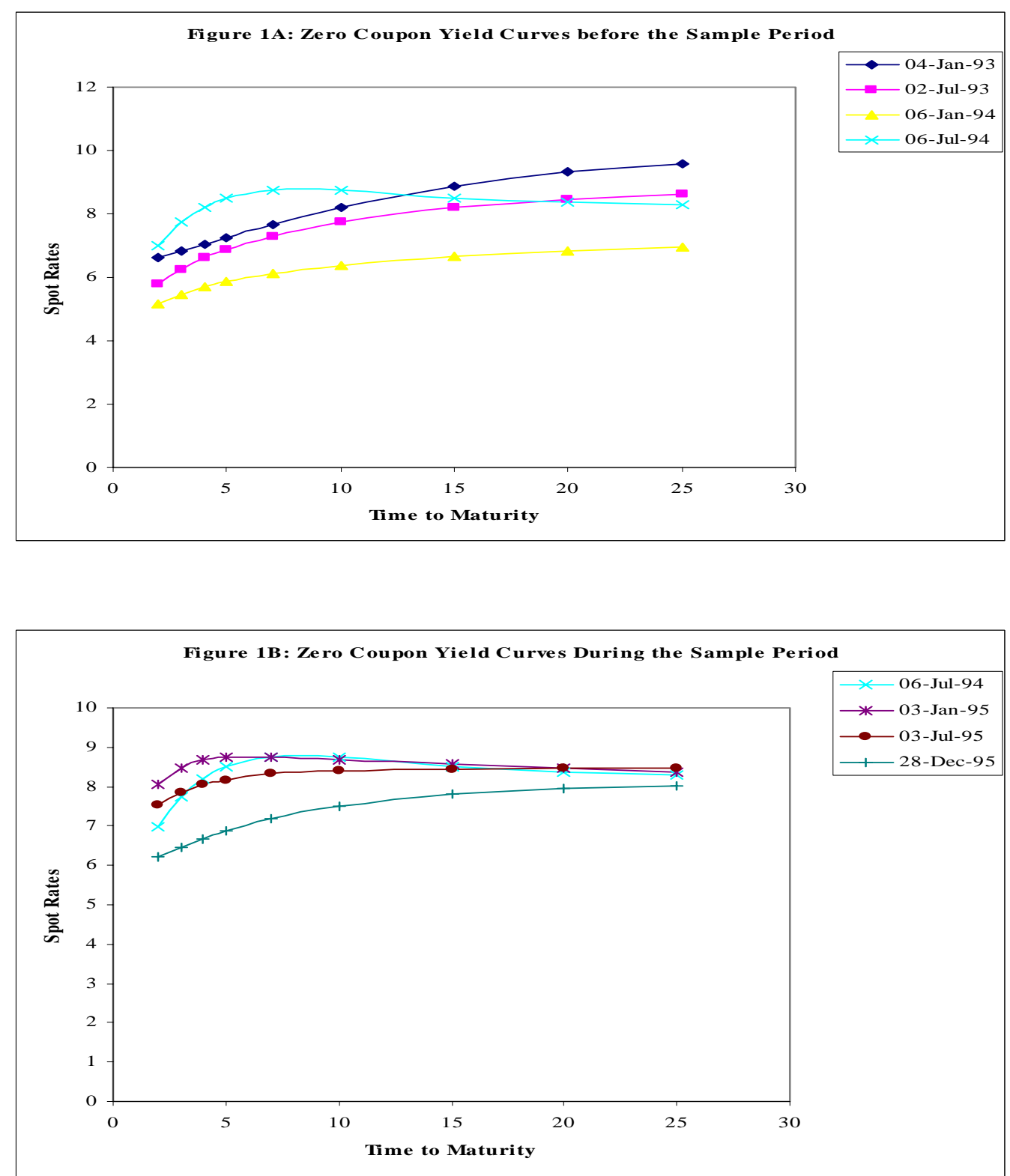

Figure 2: Beta versus Duration of Individual Bonds






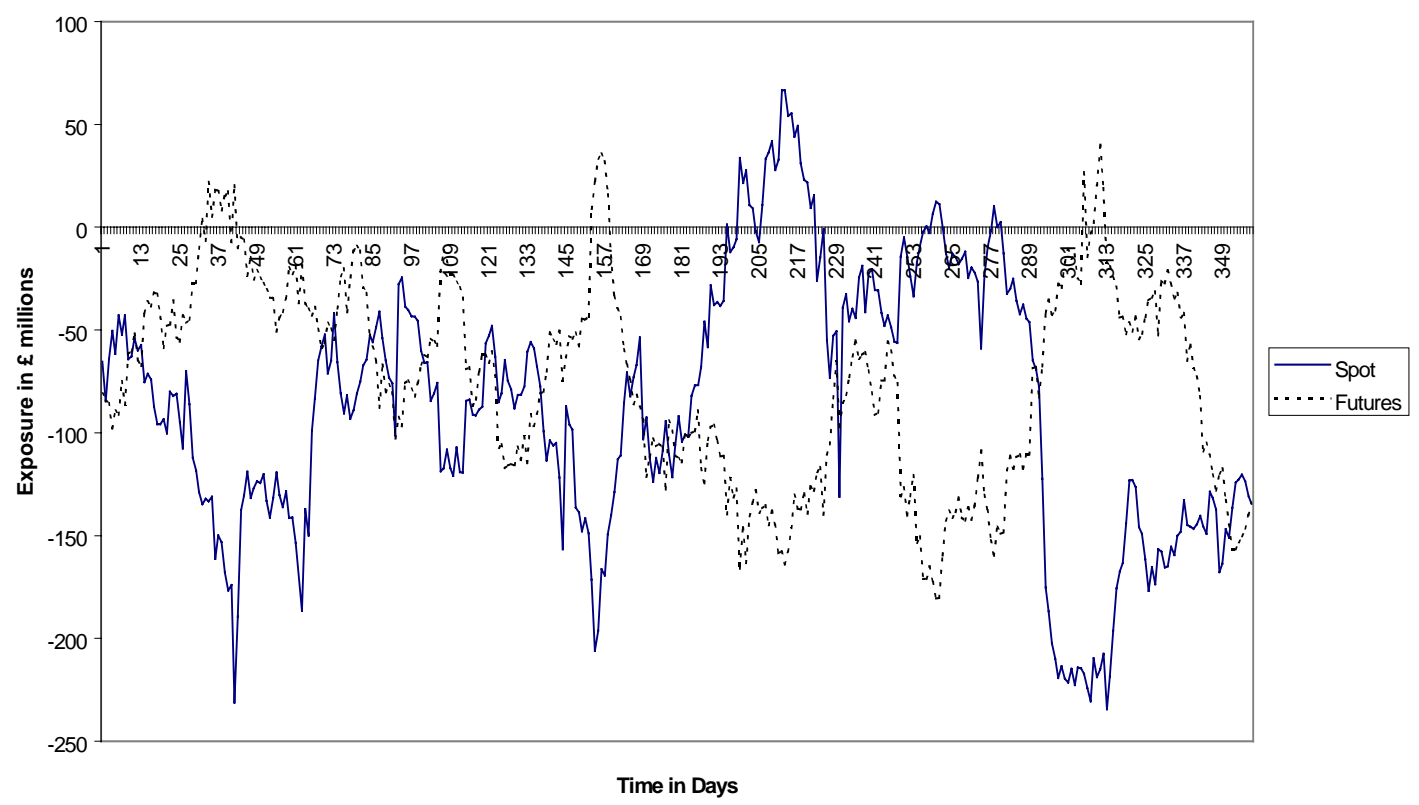

Figure 4: Evolution of the 'Empirical Measure" of Spot and Futures Exposure over Time for the fifteen Dealers as a Group

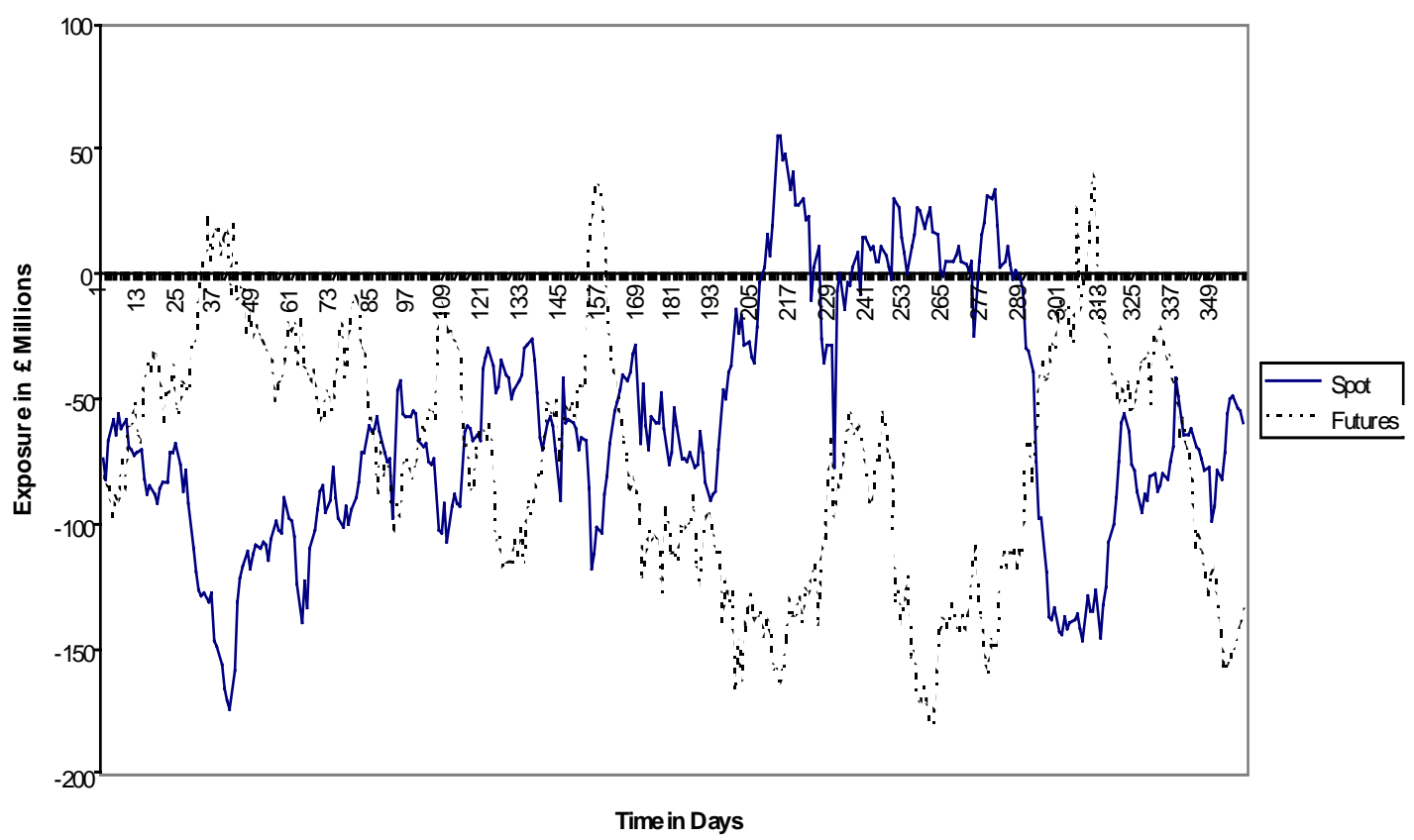


Figure 5: Evolution of the Empirical Measure of Total (Spot-plus-Futures) Exposure over Time for the fifteen Dealers as a Group

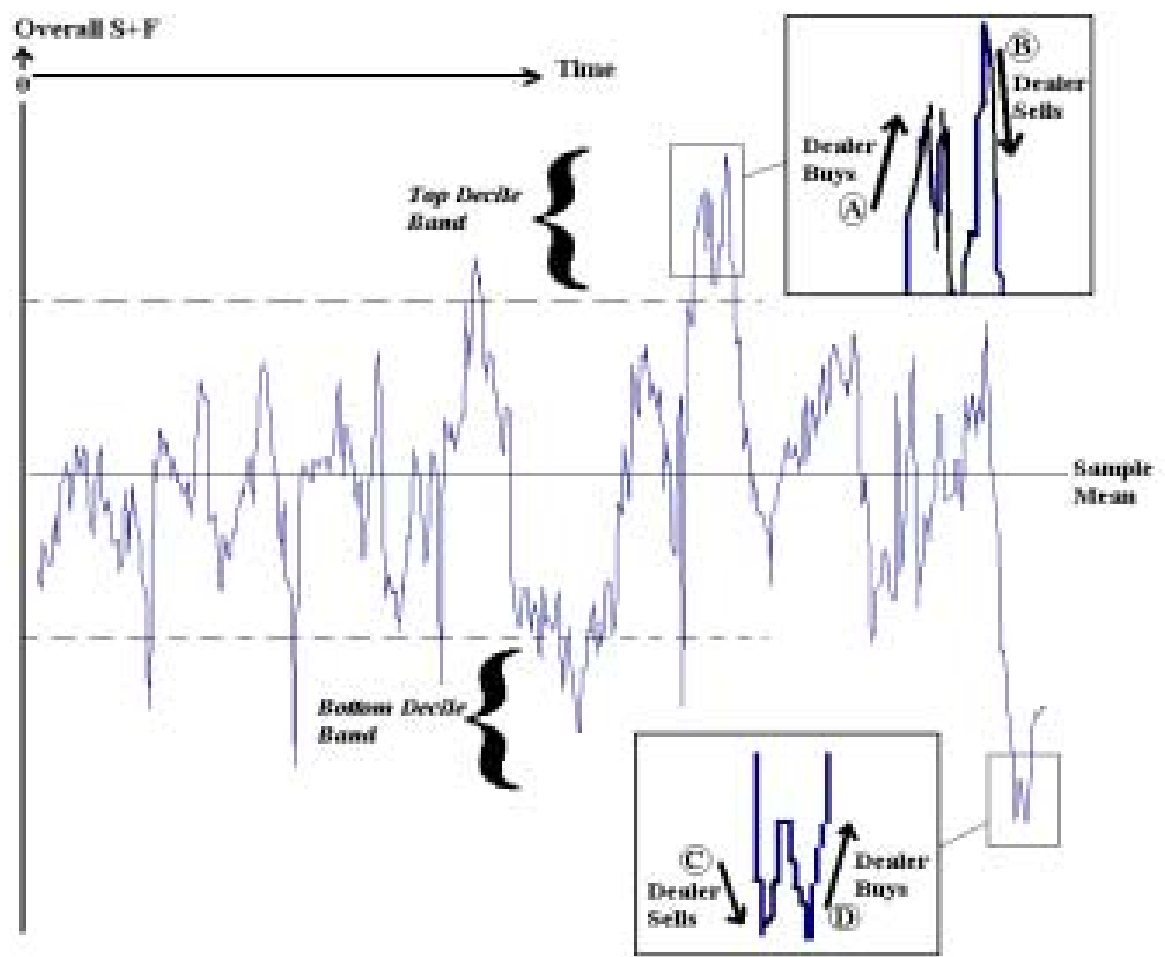


Figure 6: Change-in-Exposure (Total, Futures or Spot) Rank versus Exposure-level Rank Panel A: Average Change in Total (Spot-plus-Futures) Exposure Rank

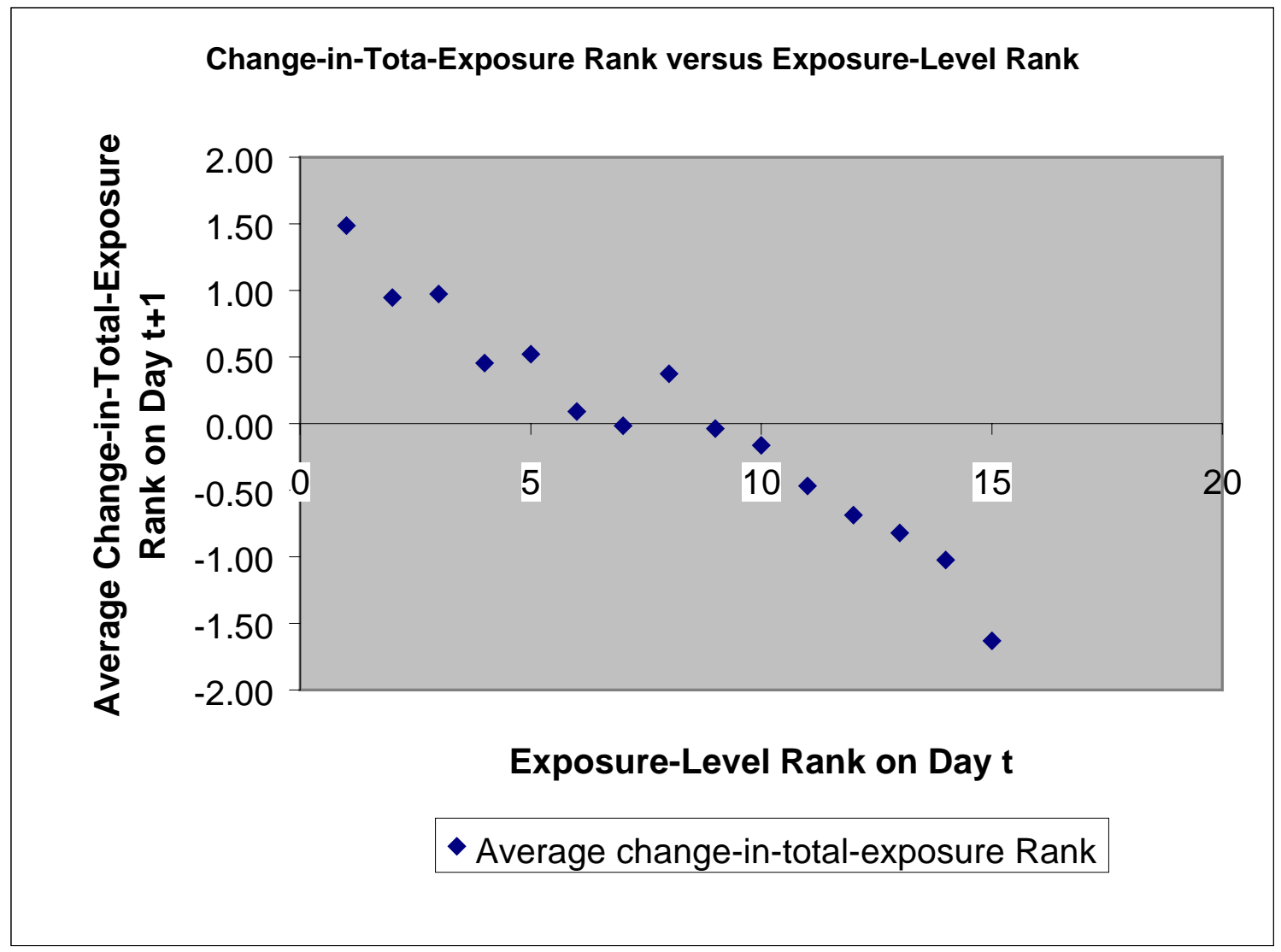

Panel B: Average Change in Futures Exposure Rank

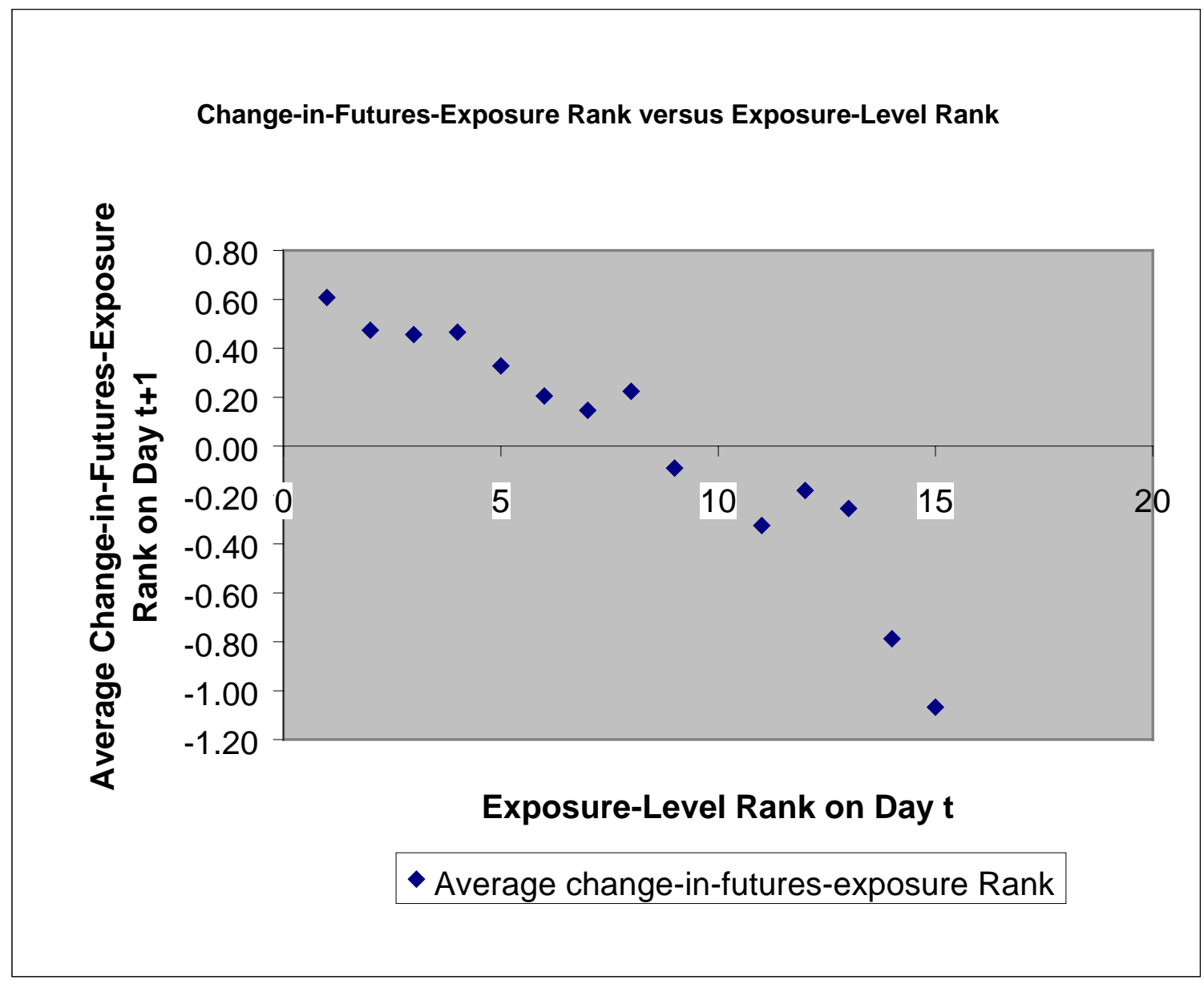


Panel C: Average Change in Spot Exposure Rank

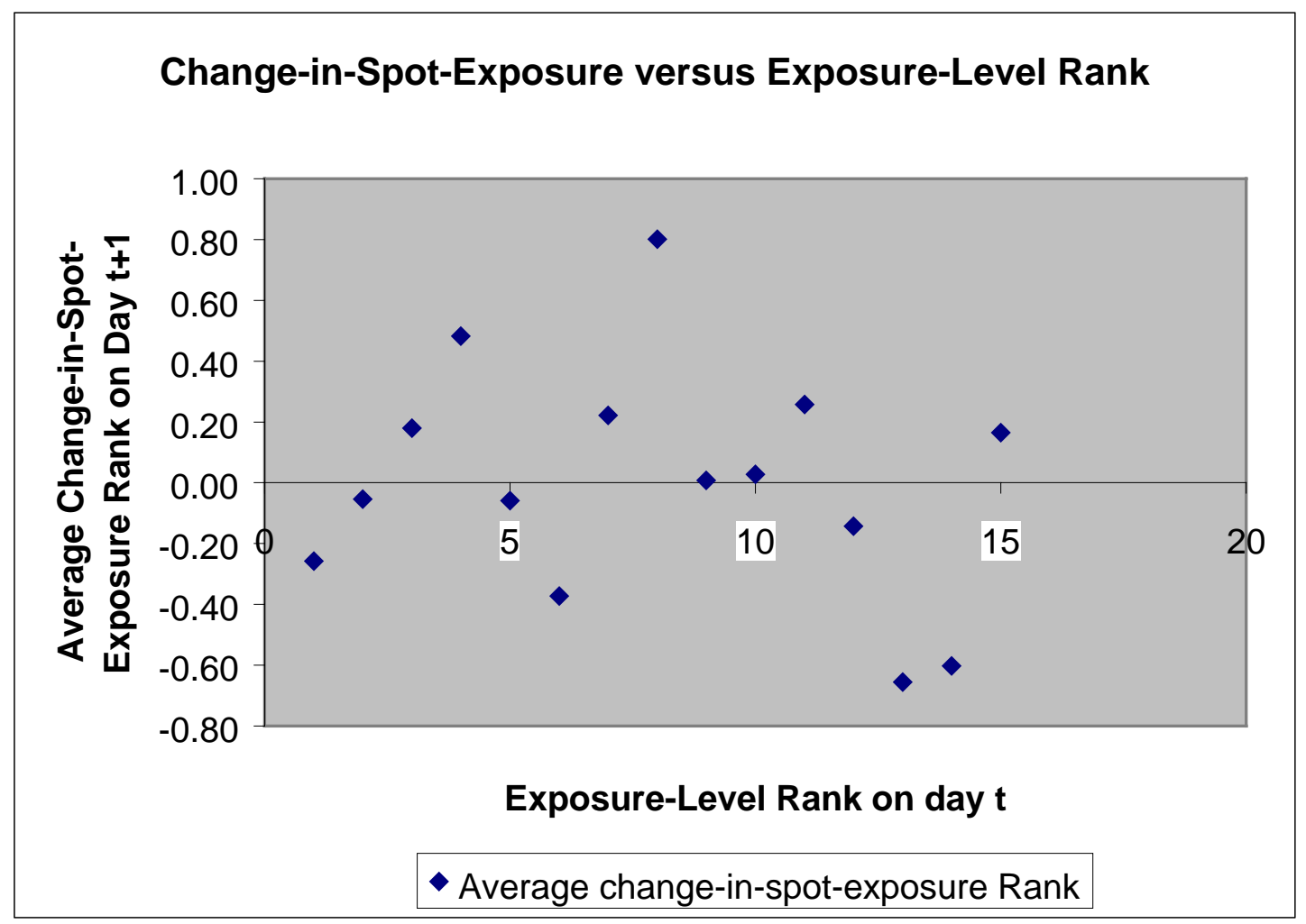

